Portland State University

PDXScholar

1979

\title{
Impact of the Older Americans act of 1965 upon the elderly in Portland-Multnomah County, Oregon, from 1965 to 1977
}

Joil A. Southwell

Portland State University

Follow this and additional works at: https://pdxscholar.library.pdx.edu/open_access_etds

Part of the American Politics Commons, and the Elder Law Commons

Let us know how access to this document benefits you.

\section{Recommended Citation}

Southwell, Joil A., "Impact of the Older Americans act of 1965 upon the elderly in Portland-Multnomah County, Oregon, from 1965 to 1977" (1979). Dissertations and Theses. Paper 2907.

https://doi.org/10.15760/etd.2903

This Thesis is brought to you for free and open access. It has been accepted for inclusion in Dissertations and Theses by an authorized administrator of PDXScholar. Please contact us if we can make this document more accessible: pdxscholar@pdx.edu. 
AN ABSTRACT OF THE THESIS OF Joil A. Southwell for the Master of Science in Political Science presented July 26, 1978.

Title: Impact of the 01der Americans Act of 1965 Upon the Elderly in Portland-Multnomah County, Oregon, 1965 to 1977.

APPROVED BY MEMBERS OF THE THESIS COMMITTEE:

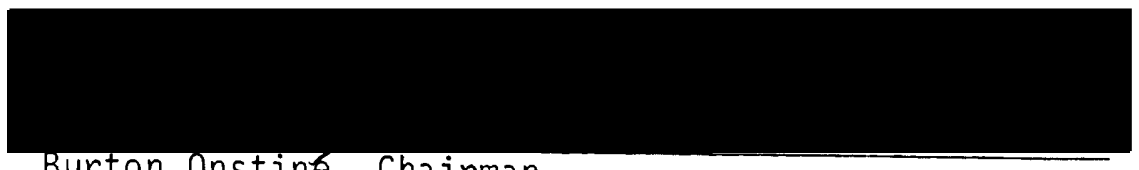

Burton Onstine, Chairman

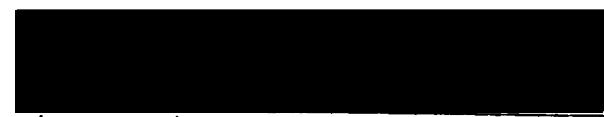

Leonard D Cain

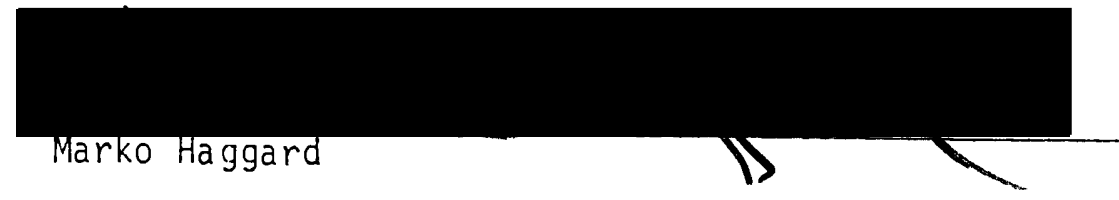

My personal interest in aging was aroused during the last year of my paternal grandfather's life (1946-47). I frequently recall many fond and vivid impressions of what it was like to be an elderly person. Those impressions have prompted my continuing acute awareness of the usefulness of the elderly, as well as the numerous problems that inevitably confront most of that population. Hence, it is not a coincidence that for a major portion of the past 15 years, I have lived and worked with elderly persons under numerous circumstances and conditions. Thus, the passage of the 
01 der Americans Act of 1965 triggered my curiosity as to the Act's impact and significance on the aged population in Portland and Multnomah County, Oregon.

This research sought to determine the impact of the 01 der Americans Act of 1965 and its subsequent amendments on the aged population in Portland-Multnomah County from 1965 to 1977. After a comparative analysis of aged services prior to the Act of 1965, and the elderly services subsequent to the Act, the conclusions revealed that there was significant impact made upon the lives of seniors in Portland-Multnomah County area.

This study identifies the historical events that led to the 01 der Americans Act. This includes the evolution of aging conscious-. ness in the local, state, and national communities. In addition, the major goals and objectives of the Act are identified.

Interviews were held with numerous elderly recipients, professional staff of aging projects, and civic leaders. These interviews were conducted informally at meetings, potlucks, and other special social events.

My conclusions are based on a comprehensive analysis of scores of interviews, review of numerous evaluative reports of aging programs, plus my actual working experience with the elderly in many capacities for the past 15 years.

While numerous suggestions and ideas were presented to me, I accept full responsibility for the issues that are expressed at any point in this study. 
If my recommendations are followed by local (City of Portland) government, future aging services may have more profound effects on the lives of elderly citizens. 


\title{
IMPACT OF THE OLDER AMERICANS ACT \\ OF 1965 UPON THE ELDERLY IN \\ PORTLAND-PULTNOMAH COUNTY, OREGON, \\ FROM 1965 TO 1977
}

by

JOIL A. SOUTHWELL

A thesis submitted in partial fulfillment of the requirements for the degree of

\author{
MASTER OF SCIENCE \\ in \\ POLITICAL SCIENCE
}

Portland State University

1979 
TO THE OFFICE OF GRADUATE STUDIES AND RESEARCH:

The members of the Committee approve the thesis of Joil A. Southwell presented February 23, 1979.

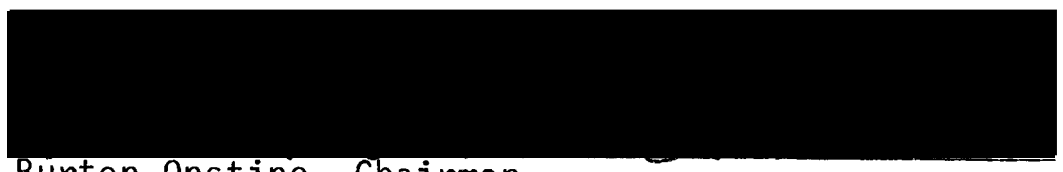

Burton Onstine, Chairman

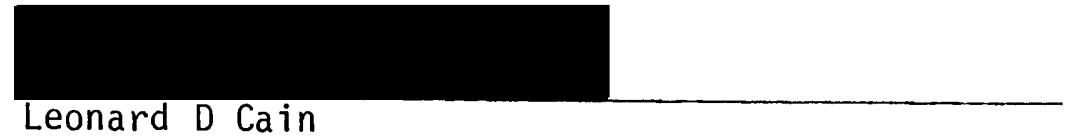

Leonard D Cain

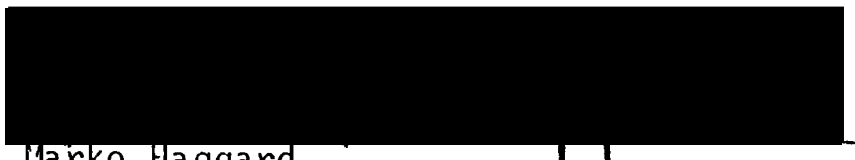

Tharko Haggard II

APPROVED:

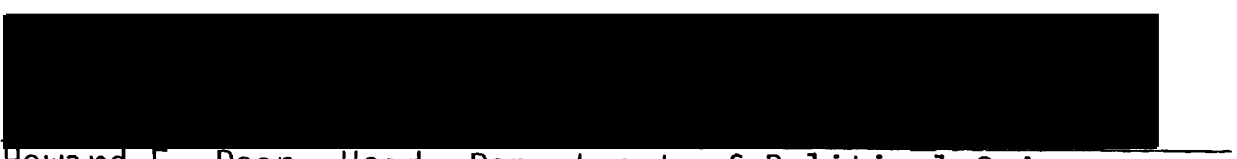

Howard E. Dean, Head, Department of Political Science

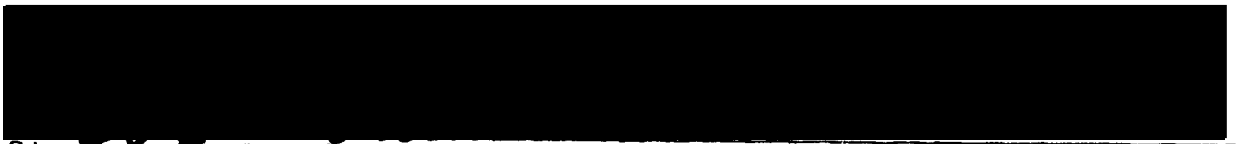

Stantey E. Rauch, Dean of Garaduate Studies and Research 


\section{ACKNOWLEDGEMENTS}

I would like to thank nembers of my committee, Dr. Burton Onstine, Dr. Leonard Cain, and Mr. Marko Haggard for their endeavors and support. I am particularly thankful to Dr. Onstine, who encouraged me to pursue a thesis instead of a practicum. I am certainly appreciative of Dr. Cain's constructive criticism as well as the data he contributed. Drs. Cain and Onstine's guidance and suggestions were, indeed, inspirational. I am indebted to the elderly population of lultnomah County and many other senior citizen advocates for their cooperation in divulging so much pertinent information. Their kind deeds made my study more enjoyable and profound. Jim Kline's assistance in many phases of the project was invaluable. Finally, I am extremely grateful to my wife cynthia for her untiring efforts and encouragement during the entire study. 
TABLE OF CONTENTS

PAGE

ACKNOWLEDGMENTS ...............................

CHAPTER

I HISTORICAL ANALYSIS OF ELDERLY PROBLEMS PRIOR

TO 1966............................ 1

Introduction. ............. . . 1

The Aging Context . . . . . . . . . . 3

Physical and Mental Health of the Elderly... 10

Developments in the Metropolitan Portland-

Multnomah County Area .......... 18

II THE OLDER AMERICANS ACT OF 1965.......... . . 20

Declaration of Objectives ......... 22

State and Community Programs Up Until

March of 1973.............. 27

Nutrition Programs for the Elderly ...... 31

III POLITICAL ORGANIZATION .................. 39

Function of the Council ......... 45

Purpose of the Oregon State Program on Aging. . . 49

Volunteer Organizations of the Elderly Persons. . 60

IV SOME SPECIFIC TYPES OF IMPACTS OF THE OLDER

AMERI CANS ACT IN PORTLAND-MULTNOMAH AREA . . . . . 72

Inventory of Elderly Services Prior to

1965 in City of Portland-Multnomah County.... 
CHAPTER

PAGE

Demographic Characteristics of Elderly Needs

in Portland-Multnomah County 1968-1975 . . . . . 75

Development and Expansion of Aging Services

in Multnomah County........... . 81

Specific Effects of the 1973 Amendment of

the 01 der Americans Act ........... . 97

Comprehensive Aging Plan Since the Existence

of the Area Agency on Aging ........... . 99

$\checkmark$ SIGNIFICANT ACHIEVEMENTS OF THE OLDER AMERICANS

ACT IN THE PORTLAND-MULTNOMAH AREA. ....... 101

Alternatives to Commitment ........ 120

Roles and Activities for the Aged ....... 124

VI CONCLUSIONS AND RECOMMENDATIONS ......... 129

Major Recommendations.......... 135

PREFACE TO BIBLIOGRAPHY ................. 138

BIBLIOGRAPHY .................. 142

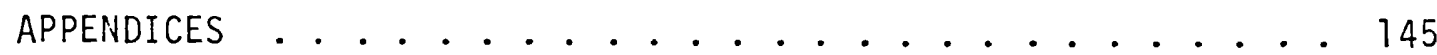


CHAPTER I

HISTORICAL ANALYSIS OF ELDERLY PROBLEMS PRIOR TO 1965

\section{INTRODUCTION}

Some of the political events that led to the passage of the 01 der Americans Act of 1965 originated in 1883 when the state of California approved legislation that provided funds for institutional care for the aged indigent (Harvey 1936). This legislation provided a meager assistance to those persons who were in dire need. Even more iniportant, it sparked enthusiasm throughout neighboring states such as Washington and Oregon.

In 1903, California adopted a more comprehensive state welfare system for the aged, as well as other indigents, with the establishment of a State Board of Charities and Corrections (Bornet 1960).

After the abortive Pension Act of 1883, California, along with most states, seemed to lose interest in ord age pensions until the mid-1930's. During the interim, it was primarily volunteer organizations that spoke on behalf of the aged (Lubove 1967). On the national scene, the most important of these were the Fraternal Order of Eagles (FOE), Abraham Epstein's American Association for Labor Legislation (AALL), and various other labor organizations. With the passage of President Roosevelt's New Deal legislation, the Social Security Act provided additional benefits in the form of old age assistance, as well as medical services. 
In 1950-1952, President Truman held what is usually considered the first formal senior citizens' conference with at least 800 persons from throughout the country in attendance. The senior citizens' concerns picked up momentum to the extent that in 1961 John R. Fogarty from Rhode Island introduced legislation that provided each state with at least $\$ 15,000$ in order to plan and submit major recommendations to the first White House Conference on Aging in 1961. The results of this first White House Conference on Aging culminated in the passage of the 196501 der Americans Act. 
THE AGING CONTEXT

I have worked with the elderly in the Portland metropolitan area for the past 15 years. During this period I have been made acutely aware of the problems the elderly person encounters on the local, state, and national levels. These are more than just political, legislative, and administrative problems. In fact, it is the physical, psychological, social, and economic problems encountered by the elderly that makes growing old an extremely difficult experience.

It is somewhat ironic that our society seeks to use scientific knowledge and skills to improve health and thus extend the life span, while continually emphasizing youthfulness. Growing old is a process which begins with life itself. Yet we, as a society, attempt to hide age with hair transplants, face lifts, health clubs, and cosmetic products. The tragedy is that the recent development of a cult of youth has minimized our chances for enjoying old age.

One of the most significant changes that occurs with age is in the area of work. Although workers are protected until the age of 65 against discrimination on the basis of age, as one gets older one faces a general reluctance by many employers to employ or promote older workers (01der Americans Act 1965). This slows advancement to better paying jobs. Once the age of 65 is reached, retirement typically occurs. The age at which enforced retirement is allowed has recently been changed to age 70 , through amendments to the Age 
Discrimination in Employment Act. These amendments will have positive implications for elderly workers. The purpose of the Act is to prohibit discrimination on the basis of age. In effect, the Act protects persons of all ages. Effective January 1979, it provides, subject to express limitations, that:

[W]o person in the United States shall, on the basis of age, be excluded from participation in, be denied the benefits of, or be subjected to discrimination under any program or activity receiving federal financial assistance. (01der Americans Act 1965)

As a result of this Act, retirement may not be as traumatic for millions of Americans. Prior to January 1979, retirement meant for many the loss of significant social roles, a feeling of uselessness, in addition to the loss of economic power and visibility. The pattern of life also changed as the key center of activity--"the job"--was removed.

Society tends to categorize people according to their social roles or activities. A newly retired person is suddenly placed into obscurity unless he or she is financially wealthy and/or politically powerful. The once clear and important social roles of a person become blurred, or as one elderly man stated, his life became "empty." The aged are frequently looked upon as a burden on both society and relatives, a perspective which is valid to a minor extent. Some elderly do experience an array of problems related to physical decline caused by old age: However, we as a society have contributed to this problem. The relative economic growth of certain segments of society has caused purchasing power to increase for the elderly poor, which in turn creates a sharp increase in prices of everything from canned goods to houses: 
The decade of the 1960's ended with an annual Consumer Price Index rise of six percent (Holt 1971). Between 1971 and 1974 the overall annual increase was 6.9 percent; however, food prices rose 10 percent annually, while housing costs rose 6.4 percent during the same period. Where wages and inflation rise correspondingly, the effect is mitigated. However, the elderly are generally on fixed incomes which rise at a slower rate, and have suffered as a consequence of this inflation. In recent years Social Security laws provide for inflationary Social Security benefits; however, those increases have not kept pace with the major spiraling costs of medical care, foods, etc.

We have only recently come to realize that the elderly have problems. Moreover, the aged have only recently been recognized as a significant segment of society. Specifically, Margaret Huych (1974) in "Growing 01der" traces this recognition back to 1910 .

Aging has been recognized as a social problem primarily because people are living longer now than they did in earlier times. The life expectancy for white males born in 1900 was 47 years; for white females, 49 years; for black males, 32 years; and for black females, 34 years. The corresponding 1 ife expectancies for those born in 1970 were 68 years for white males, 75 years for white females; 60 years for black males, and 69 years for black females. (Loether 1975)

This means the average 1 ife expectancy for Americans increased by 24 years between 1900 and 1970 .

In 1900, the United States had about three million people ( 4.1 percent of the population) who were 65 years of age or older. As of July 1, 1971, the over 65 population reached 20.5 million ( 9.9 percent). Next to persons between the ages of 14 and 24 years, persons over 65 had the fastest rate of increase of any age category: their net increase was approximately 1000 persons per day. At the turn of the century, the aged did not constitute a social problem, because there were relatively few people who lived 
to the age of 65 . Men who reached the age of 60 in 1900 could expect less than three years of 1 ife in retirement in contrast to eleven years for men who reached 60 years of age in 1969. In 1900, men usually died before they reached the age of retirement. Retirement was so rare it had not yet become institutionalized. When it did occur, it was limited to those in the ligher income brackets. The Social Security Act of 1935 firmly established 65 as the age of retirement. (Loether 1975)

The increasing awareness by some that the elderly constituted a seyment of the population with growing problems spurred the first National Conference on Aging in 1950. This conference was held at the request of President Harry S. Truman and marks the beginning of a national effort to identify and correct the problems of the elderly. It was estimated that at least 800 delegates attended the 1950 National Conference on Aging. While some of the current problems of elderly (inadequate health care, low income, inadequate housing, etc.) were presented, perhaps the most outstanding accomplishment was the establishment of a format by which future aging conferences would be conducted. By 1952, numerous conferences on aging were being conducted throughout the United States. These conferences served as vehicles to develop and implement key legislation for the aged poor.

Urged by this growing concern with the problems of the elderly, the 85th Congress passed an act on September 2, 1958, which called for the first White House Conference on Aging in January 1961. The act, sponsored by John R. Fogarty of Rhode Island, provided $\$ 15,000$ in federal funds to each state. The monies were to be used to finance participation in the conference.

As a result of the appropriation of these funds, each state established a committee to develop recommendations for the conference. The 
information gathered by each state varied widely in comprehensiveness. However, the reports did contain inventories of resources and needs.

In $1950,8.7$ percent $(133,021)$ of Oregon's population were "older people." Since then, the State's population has advanced to over 1,625,000. The old age population is increasing at the rate of about 3000 per year. Every day of the year, there are between eight to ten new 65 year-old citizens in Oregon. During the lifetime of persons now 60 years old, the percentage of older people in Oregon has increased 1431 percent, or 4-3/4 times as fast as general population of the state. (Report of Governor's Committee 1954)

About one-sixth of all persons 65 and over are supported by relatives. In 1950, half the aged persons living alone, or with no relatives, had cash incomes of less than $\$ 650$. 01der people generally tend to live more economically--rent smaller houses; guard against mortgages, installment buying, and replacements; spend less on clothes and, of course, spend less on food (Portland Housing Authority 1959).

Two out of every five people in Oregon (39.6 percent) past the age of 65 receive old age insurance payments, or 396 per 1000 population. This is nearly two and one-half times as many persons as are receiving 01d Age Assistance benefits.

In 1952, Oregon ranked eighth among the states in percent of its people receiving 01d Age Survivors Insurance. In December 1952, 37,533 persons 65 and over living in Oregon received OASI Benefits for a total amount of $\$ 1,802,952$. In November 1954, the number of beneficiaries exceeded 84,000 , the monthly payments $\$ 40$ or $\$ 50$ million a year.

Generally, the problems of the elderly in Oregon and particularly in Multnomah County were similar to those in the rest of the United States. There were basically (a) lack of adequate income or earnings, (b) inadequate and insufficient housing, (c) poor health care, (d) a lack 
of transportation services, and (e) inadequate information about those agencies that provided services for the elderly (White House Conference 1971).

The Bureau of Consumer Income of 1957 also revealed that 60.3 percent of the elderly in Multnomah County had incomes under $\$ 1000$ per year, and 20.2 percent of the elderly received between $\$ 1000-1999$. Approximately 7.9 percent of the elderly had between $\$ 2000-3000$, 6.9 percent between $\$ 3000-4999$, and approximately 4.7 percent received over $\$ 5000$.

The living arrangement of persons over 65 was somewhat comparable to the national picture with approximately 75 percent of the elderly living in their own homes in the 1950's, and approximately 11.2 percent (compared with ten percent of the nation's population) living in rooming houses, institutions and/or with relatives. This was reported by the U.S. Census in 1950. On August 7, 1959, the Housing Authority of Portland initiated a survey primarily to determine if there was a real need for more decent, safe, and sanitary housing for senior citizens, particularly those of low income. This study was initiated by the mayor. The results of the survey proved conclusively that such an urgent need existed. For example, the old age assistance benefits ranged from approximately \$73-140 per month, and the average gross monthly family income for families whose dwellings were included in the survey was approximately $\$ 99.33$, acutely limiting the amount of money those people can afford to pay for standard housing. Seventy-five percent of Portland's indigent elderly, of whom more than 5000 depended wholly or in large part on old age assistance, were housed in substandard dwelling units. The most shocking and shameful fact was that so large a percentage 
of our senior citizens were living in accommodations that were not decent, safe, nor sanitary; conditions which were only brought to light by the survey completed in August 1959. The ten percent sample was distributed graphically, in direct proportion to the concentration of the population in the city. Dwellings in nearly every Portland district were included in the survey. Eighty-three percent of the dwellings were tenant-occupied, and 17 percent were owner-occupied. of the 500 dwelling units surveyed, these facts were developed: 161 cases of inadequate ventiliation; 137 instances of unsafe staircases; 107 dwellings not free from vermin, filth, and garbage;

49 sinks not in good working condition and 47 other improper and inadequate plumbing facilities; and 168 cases in which walls and ceilings were in bad repair. This study also revealed that more than 30 percent of the dwellings were found to be in violation of three or more code requirements; 17 percent were in violation of five or more code requirements; and one dwelling, virtually a "paper shack," was in violation of nearly all code requirements. On the basis of these 1959 findings, the Portland Housing Authority was able to obtain substantial federal funds to develop various housing units for the elderly.

It was stated by the Housing Authority of Portland in its desire to initiate a breakthrough of decent housing for the elderly that the City of Portland needs to address better housing for the needy and deserving senior citizen. Most older persons that I have talked to in centers throughout Portland-Multnomah County since 1971 express a wish to remain in their own homes and in the communities in which they have some roots. 
At the same time, as many people grow older, they are less able to remain alone, and many need other facilities which must be as varied in nature as are the circumstances of the people themselves. In talking with elderly persons about their dissatisfactions and preferences for housing, it was found that in the area of housingliving arrangements, at least 28 percent of the total 92 respondents expressed dissatisfaction. This interview was conducted at two senior citizen potlucks in Portland, Oregon in 1974. Housing was the area in which the fourth highest number of elderly respondents expressed dissatisfaction. Other reasons mentioned with some frequency were physical health limitations, and lack of companionship. Almost three-fourths of the dissatisfied respondents made efforts to change their housing situation. Since the enactment of Public Law 1020 in August 1956, it has been possible for single elderly persons of low income to obtain private housing. The Law also permitted low rent public housing projects. The Housing Act of 1959 further amended the basic law, which provided for all persons age 65 and 01 der, by lowering the age limits for elderly persons to conform to those under the Social Security Act--65 years for men, 62 years for women, and 50 years for disabled persons.

\section{PHYSICAL AND MENTAL HEALTH OF THE ELDERLY}

Mental and physical health of the elderly were two of the nation's social problems in the 1950's and this continues to be true. Both types of health concerns have been receiving national attention within the past two decades, and it is evident that tremendous efforts are being made to address these problems in the 
years ahead. The health of our senior citizens depends upon financial security, employment, housing, spiritual living, recreation, and other everyday factors of living that affect all ages. The mental health of our older population was difficult to analyze. It was found that in 1956-60, 21.8 percent of the patients in residence at the state hospitals in Oregon were over 65 years of age. It was expected that this number would rise somewhat due to increased longevity. This percentage compares with a national average of 30.5 percent over 65 years old of patients confined in mental institutions. Twenty percent of first admissions to state hospitals are over 65 years of age (U.S. Department of Health, Education and Welfare 1976).

In addition to the institutionalized elderly in nursing homes and hospitals, there was an estimated 14 percent of the elderly population needing in-home assistance. This means that there were approximately 31,752 elderly persons at risk in the state--21,177 of those had their needs unmet. In "Measuring the Home Health Needs," published in the Journal of Gerontology, Ethel Shanas has found that approximately 14 percent of the noninstitutionalized elderly population is at risk: two percent are bedfast, six percent are housebound, and an additional six percent are ambulatory but experience some difficulty. The following is an approximate breakdown of the state of Oregon's elderly persons: state elderly population was 226,799; noninstitutionalized population at risk was 31,752 persons; persons receiving aid through home health agencies was 3,197; homemakers served 439 persons; adult foster homes 442 ; household helpers/old age assistance 497--total persons served 4,575. One third of those persons with uninet needs $(21,177)$ were located in Multnomah County 
in 1960 (Budget Proposal 1975-76).

It was noted in Multnomah County that the following causes of death were higher than the national average for older persons over age 65:

Diseases of the heart

Vascular lesions affecting the central nervous system Influenza and pneumonia (with exception of childhood pneumonia)

Accidents

Chronic and unspecified neparitis renal sclerosis Hypertension without mention of heart attack

These chronic diseases, with the exception of venereal disease, have been found to occur more often in older age groups. As a result, the Chronic Disease Program of our state Department of Health is directed to a large extent at the older segment of our population (Oregon State llealth Division 1973).

Nutrition is one of the significant factors of good health and medical care. For instance, good health in later years is dependent upon many factors in addition to lifetime patterns of diet, patterns of exercise regularity, relaxation and sleep, and freedom from disease are closely associated with a very poor nutritional diet. The results of poor nutrition may not show up until old age or periods of nutritional stress, such as suffering from an infection or recovering from surgery. It appears that during the 1950's there were basically two classes of individuals in reference to nutrition for the aged--each with distinct nutritional needs. One class consisted of elderly persons who were unable to purchase nutritional foods due to lack of 
adequate finance. The other class of seniors were too lonely to eat.

First class food must be selected to suit the nature of the infirmity or illness, such as the ill-fitting dentures and anemias, constipation, an infectious and degenerative disease. For the well, a good general diet which contains basic nutritional substances (carbohydrates, proteins, fats, minerals, and vitamins) is important.

It was evident in talking to scores of senior citizens that those who had regular well-balanced diets were by far more content and responsive and active in all respects. It is general knowledge that the brain functions far more effectively when adequate nutrients are being fed to the body.

\section{LACK OF TRANSPORTATION SERVICES FOR THE ELDERLY}

In our society, there is a tendency to make it more and more difficult for the elderly to have access to those basic services which make life desirable and sometimes possible. This was the condition that existed prior to the 1960's. The needs of the elderly (food, income opportunity, welfare, education, recreation) and the general need to participate in the life of the community were made increasingly difficult for fulfillment because of one of theirmost "critical" needs, that of transportation. The capacity and/or capability pertaining to travel in the city (Multnomah County) was more or less nonexistent. Except for church groups and few families and friends, there were actually no transportation systems in Multnomah County during the 1950's that provided exclusive services to the elderly. The Public Welfare Division does provide some transportation services on a limited basis, but it was very minimal for Public Welfare clients. 
The lack of special transportation services for the elderly in the 1950's produced severe adverse effects in terms of mobility for the elderly. For example, it was increasingly difficult for them to obtain proper medical services, to travel to stores, to participate in community activities, and to take advantage of the existing community resources. The lack of adequate transportation services for the elderly generated a major concern. Hence, special transportation service was recommended to the White House Conference on Aging in 1961 as a priority.

It was also very evident that there was a lack of community services that would normally provide social assistance to the elderly during the 1950's. Of course, this is still true today. But, even more astonishing was the fact that only 60 percent of the approximately 66,000-70,000 elderly in 1958 were knowledgeable about available resources (Portland Housing Authority 1959). This indicates some of the grave service needs that existed then, and in some degree, they exist today.

The elderly person often experiences a wide array of problems, including physical and financial decline associated with old age in this society. Many elderly persons who remain in their own homes suffer from neglect because they do not utilize available resources that meet their needs. In 1975 an elderly, blind gentleman at one of the monthly potlucks sponsored by a senior service center, stated that it was the first time in three years he had left his home. Others who were institutionalized could be provided with essential services in their own homes at a lower cost to the taxpayers. National priorities have established that the greatest need for services is 
obviously among the low income, minority and socially isolated elderly persons. The 1960 census data showed that approximately 15 percent of the population in Portland-Multnomah County (77,000 persons) were aged 65 or over, an estimated 30 percent $(16,000$ persons) of persons with incomes below the poverty level are 60 years of age or older. Also, today it is estimated that 34.4 percent $(21,176)$ of persons with incomes below the poverty level are age 60 or older. An estimated 23,474 elderly persons live alone in Portland-Multnomah County, and 2,915 are of minority ethnic heritage.

Prior to 1960, major services for the elderly were only administered by Federal Housing Administration, Social Security, Medicare, and the state Public Welfare Commission. Some local churches and private clubs did provide some or a few mini-type services; however, such services were of little or no significance.

The major issues in all the reports that were submitted to the White House Conference on Aging in January 1961 served as technically the basis for the 196501 der Americans Act. The lack of adequate income, employment, transportation, suitable housing, efficient community services, and health services, etc., were some of the elements that constituted the 01 der Americans Act of 1965. In addition, the 1961 White House Conference raised national, state, and local consciousness of the elderly persons. Since this major conference in Washington, D.C. with senior citizens, groups began to form within churches, within labor groups and other social groups in the local community. In assessing the political sensitivity in terms of the politician, interest was at a minimum during the early 1960's in Portland-Multnomah County, and for that matter, the entire state of Oregon. This is not 
to deny that state politicians did follow the national trend; but in comparison to the activities of politicians at various senior centers during the last national election, there was very little stress placed on the priorities at the local level (1960-64) as testified by many community leaders in the field of aging.

After the White House Conference in 1961, the aging issue experienced an evolution. The 1965 Oregon legislature was very active-at least it paid some attention to some local issues on aging. Various comnittees were meeting on a fairly regular basis. Specifically in Portland, many church groups and labor groups were talking about programs that were needed for the elderly, and it was due to these various discussions that political pressure throughout all the states impressed upon the minds of the Senate and House of Representatives of the U.S. Congress that it was time to pass legislation that would permit local government to provide the types of services that the elderly needed.

The 1961 White House Conference had the following specific impact upon the nation, upon the state, and certainly upon Portland-Multnomah County: (1) it identified specific needs of the elderly; (2) it raised or magnified the possible or the potential collective force of the elderly; (3) it revitalized enthusiastic interest among more elderly groups; and (4) it dramatized the cause of human dignity for the elderly, which initiated some leadership among various interest groups, such as the churches, labor and social service organizations. Hence, with the passage of the 01 der Americans Act of 1965, programs were discussed and planned on the state and local levels. As a result of these discussions, Multnomah County initiated the first county-wide 
meeting that technically dealt with specific aging problems throughout the Portland-Multnomah County area. One of the most outstanding interest groups in Portland-Multnomah County area during the early 1960's was the American Association of Retired Persons (AARP), which is a nationwide nonprofit organization with more than one million persons aged 55 years and above. One and one-half percent of the total membership was active in local chapters around the United States as of June 1968. Oregon had 13 local chapters, with an active membership of 2,800 persons, 1,300 of whom 1 ive in Multnomah County.

Technically, the motto of the AARP is "the answer for older persons who believe that the way to keep young and maintain independence and dignity is through activity, usefulness, and service to others" (American Association of Retired Persons 1968). The AARP has been a vigorous supporter of legislation to benefit the aged, both in local chapters and in Washington, D.C., where its representatives testify before the Congressional committees. Of particular interest to the AARP are efforts to improve existing Social Security laws, the Medicare legislations, and measures to prevent discrimination on the basis of aging in the employment field.

Another one of the oldest advocate groups is known as the "Friendly House," which was located in Northwest Portland. Since 1943, the First Presbyterian Church responded to some elderly needs in the northwest neighborhood. The motto of the Friendly House program since 1943 was to engage in meeting the needs of the lonely, isolated and often frail and aged persons (also see Senior Citizens Clubs--Multnomah County for description of Friendly House activities 
for the aged, as well as other Senior Citizens Clubs' activities and interests relative to the elderly).

DEVELOPMENTS IN THE METROPOLITAN PORTLANDMULTNOMAH COUNTY AREA

Once the 01der Americans Act of 1965 was passed in July 1965, Multnomah County assigned a staff person who began to assess the needs of the elderly in this vicinity on October 6,1965 . In an interview with 0 . J. Gates, who was the employee for Multnomah County assigned to do the initial planning, a needs assessment was conducted for approximately one year before an official meeting of the Portland City Council and Multnomah Board of County Commissioners. It was due to the information which was gathered by Multnomah County staff that a meeting of the City-County Coordinating Committee was held on llarch 13, 1967, at Multnomah County Courthouse. For a more detailed account of the conditions that were present at the first major meeting, at which time the Ad Hoc Interim Committee presented their report, see Appendix A.

As a result of the meeting between both governments--that is, Portland City Council and the Board of Multnomah County Commissioners, the City-County Council on Aging was established with the authority to coordinate, plan and implement programs for the elderly in Multnomah County in 1967.

A11 aged persons, at some point or another in senescence, share some common concerns. As a phase of life, aging presents a 
series of challenges (usually involving change-pleasure or crisis) with which the individual must cope to survive and function. This fact holds true for all phases of life. Senescence, however, occurs within a rather negative socio-cultural milieu at a point in life when a person may be least able to cope with the clusters of stress and crisis situations that may occur. For some older people, the changes may be gradual and gentle. For others, they may be traumatic and sudden. For almost all older persons that were interviewed or observed, this stage offers a series of losses:

1. Loss of social identity (which may include loss of work role, identity losses related to changes in family roles),

2. Loss in income,

3. Loss of sexual identity,

4. Loss in health and physical capacities,

5. Loss in relationships: gradual isolation and loneliness (SauT 1974).

Conversely, most older persons have made great gains or achievements:

1. They have gained wisdom and knowledge, which can only be obtained through a long lifetime.

2. Many elderly persons are finally able to share some of their time and talents with the less fortunate person.

3. Due to their vast experience, the elderly are some of the most outstanding teachers.

In the next chapter, the goals and objectives of the 01 der Americans Act will be analyzed in terms of its implications for the Portland-liultnomah County area. 


\section{CHAPTER I I}

\section{THE OLDER AMERICANS ACT OF 1965}

On July 14, 1965, President Lyndon B. Johnson signed into law the 01 der Americans Act of 1965. Here is a synopsis of the legislative history of the Act as it relates to the purposes and the objectives of this historic legislative landmark for senior citizens in America.

First, on February 21, 1963, President John F. Kennedy became the first president of the United States ever to send to the Congress a special message relating to our elderly citizens. In effect, President Kennedy's message stated that the basic statistics in aging, housing, and health are both revealing and disturbing. He also stated that the average income at that time by aged couples was half that of younger two-person families. Almost half of those over age 65 living alone received $\$ 1000$ a year, and three-fourths received less than $\$ 2000$ a year. Two-fifths have a total net worth, including their homes, of less than $\$ 5000$. The main source of income of the great majority of those above 65 is from one or more of the public benefit programs; seven out of ten (12.5 million persons) in 1963 received Social Security insurance payments averaging $\$ 76$ a month for a retired worker; $\$ 66$ a month for a widow, and $\$ 129$ a month for an aged worker and wife. President Kennedy also said at that time that one out of eight people are on public assistance, averaging about $\$ 60$ per month per person, supplemented by medical payments averaging 
$\$ 15$ per month (U.S. Code 1965).

A far greater proportion of senior citizens live in inferior housing than do younger citizens (Phillips 1966). This was also confirmed by the Housing Authority of Portland, as stated in Chapter I. According to the 1960 census, one-fourth of those aged 60 and over did not have a home of their own, but lived in homes of relatives, in lodging houses, or in institutions. Of the remainder, over 30 percent lived in substandard housing that lacked a private bath, toilet or running hot water, or which was otherwise dilapidated or deficient. Many others lived in housing unsuitable or unsafe for the elderly as indicated in the study of 1959 in Portland, Oregon.

For roughly four-fifths of those older citizens not living on the farm, housing is a major expense, taking more than one-third of their income. About two-thirds of all those age 65 and over own their own homes, but while such houses are generally free from mortgages, their value is generally less than $\$ 10,000$.

Our senior citizens are generally sick more frequently and for more prolonged periods of time than the rest of the population. Of every 100 persons aged 65 and over, 80 suffer some kind of chronic ailment; 28 have high blood pressure or heart disease; 27 have arthritis or rheumatism; 10 have impaired vision; 17 have hearing impairments; 16 are hospitalized one or more times annually and require three times as many days of hospitalization care every year, as compared to those under 65 years of age. Yet only half of those 65 and older have any kind of health insurance. Only one-third of those with incomes of $\$ 2,000$ a year have such insurance. It has been estimated than ten to fifteen percent of the health care of older persons is 
reimbursed (White House Conference 1961).

These and other startling and sobering statistics made President Kennedy realize that our remarkable scientific achievements prolonging the life span have not been translated to effective human achievements. Our urban and industrialized way of life had some adverse effects upon the useful and satisfying roles which the elderly played in rural and small town family society of an earlier era. It has certainly affected some areas in our City of Portland to the extent that many elderiy are still poverty stricken. The skills and talents of our older people are still often discarded.

After President Kennedy presented the above facts to Congress, the results of the President's various committees in Congress proved very effective and instrumental in having this historic legislation passed by Congress after the death of President Kennedy. In order to get a thorough understanding of the bill, it is necessary to analyze the various sections to determine their implications as they relate to Portland-Multnomah metropolitan areas.

\section{SECTION BY SECTION AIAALYSIS OF TITLE I-- DECLARATION OF OBJECTIVES}

\section{Definitions: Section 101}

Declaration of objectives for the 01der Americans Act of 1965. The objectives of the Act are:

(1) An adequate income in retirement in accordance with the American standard of living; (2) the best possible physical and mental health which science can make available and without regard for economic status; suitable housing independently selected, designed, and located with reference to special needs available at cost which 
older citizens can afford; (4) full restoration of services for those who require institutional care; (5) opportunity for employment with no discrininatory personnel practices because of age; (6) retirement and health, honor, dignity after years of contribution to the economy; (7) pursuit of meaningful opportunity within the widest range of civic cultural and recreational opportunities; (8) efficient community services which provide social services in a coordinated manner and which are readily available when needed; (9) immediate benefit from proven research which can sustain and improve health and happiness; and

(10) freedom, independence and the free exercise of the individual initiative in managing their own lives.

(01 der Americans Act 1965)

Definitions: Section 102

Secretary--will mean the Secretary of Health, Education and Helfare.

Commissioner of the new Administration on Aging. Dr. Arthur Flemring, former President of the University of Oregon, was the Commissioner of the Administration on Aging until early 1978.

ADMINISTRATION ON AGING--TITLE II

Section 202--Functions of the Office

The duties of the Administration on Aging are to: (1) serve problems of the aging; (2) assist the Secretary in all matters pertaining to problems of the aged on aging; (3) administer the grants by the act; (4) develop plans, conduct and arrange for research in demonstration programs on aging; (5) provide technical assistance in consultation to states political subdivisions thereof with respect to programs for the ayed on aging; $(6)$ prepare, publish, and disseminate educational material dealing with old persons; (7) gather statistics in the field of aging that other federal agencies have not collected; and (8) stimulate a more effective use of existing 
resources and available services on aging (01der Americans Act 1965).

\section{GRANTS FOR COMMUNITY PLANNING SERVICES AND \\ TRAINING--TITLE III}

\section{Section 301--Authorization of Appropriations}

According to the 196501 der Americans Act, the Secretary was responsible for carrying out a program of grants for at least five years commencing with the fiscal year ending June 30, 1966. Authorization for appropriation of $\$ 5$ million for fiscal year June 30,1966 ; $\$ 8$ million for June 30; 1967; and such sums as Congress may authorize for the next three fiscal years for the following purposes are: (1) community planning and coordination of programs for carrying out the purposes of this Act; (2) demonstration of programs for activities which are particularly valuable in carrying out such purposes; (3) training of special personnel needed to carry out such programs and activities; (4) establishment of new or expansion of existing programs to carry out such purposes; including the establishments of new or existing expansions of providing recreational leisure time activities, and informational health/welfare counseling and referral services for older persons and assist such persons in providing volunteers to civic services, except that no cost of construction, other than for minor alterations and repairs shall be included in such establishment of expansion.

Section 303

Criteria for approval of a state plan by the Secretary included a single state agency, such as the state of Oregon's program on aging, 
and financial participation by the state or community in the project's activities to insure continuation after federal support was terminated. To carry out the purpose of the Act, it was al so necessary to furnish services through public or non-profit agencies or organizations; set forth principles for determining the priority of projects in the state; provide administration of personnel standards in merit base, public or non-profit agencies or organizations; and prepare state reports.

\section{RESEARCH AND DEVELOPMENT PROJECTS}

\section{TITLE IV}

\section{Section 401--Project Grants}

Grants and contracts were authorized by the Secretary with public or non-private agencies, organizations, institutions, or individuals for study, development, demonstration, and evaluation projects for the following purposes: (a) to study current patterns and conditions of living of older persons and identify factors which are beneficial or detrimental to wholesome and meaningful living of persons; (b) to develop or demonstrate new approaches, techniques and methods (including multipurpose centers) such as the Senior Adult Service Center which was established at 3904 N.E. Union Avenue, Portland, Oregon, which would hold promise of substantial contribution toward wholesome and meaningful living for older persons; (c) to develop or demonstrate approaches, methods, and techniques for achieving or improving coordination for community services for older persons; (d) to develop the approaches, techniques, and methods, as well as others that assist older persons to enjoy wholesome and meaningful 
living and continue to contribute to the strength and welfare of our nation.

\section{Section 402--Payments of Grants}

The Secretary may require contributions by recipients and payments may be made in advance or by way of reimbursement and such installments and on such conditions as the secretary may determine.

\section{NATIONAL ADVISORY COMMITTEES ON AGING--}

TITLE VI

\section{Section 601}

This section deals specifically with the Advisory Committee of the 01 der Americans Act. Congress established an Advisory Committee on 01 der Americans, consisting of the Commissioner as Chairperson and fifteen persons appointed by the Secretary, who are experienced or have demonstrated particular interest in special problems of the aging.

For the purpose of carrying out the activities of Titles IV and $V$, there were authorized $\$ 1.5$ million for Fiscal Year June 30, 1966, and $\$ 3$ million for Fiscal Year June 30, 1977, and such sums as Congress may appropriate for the next three years (Legislative History 19 ). Each member of the Committee shall hold office for a term of three years, however the terms of office of members first to be in office shall expire as designated by the Secretary of HEll at the time of appointment, five at the end of the first year, five at the end of the second year, and five at the end of the third year. After the date of appointment the Secretary is further authorized to appoint 
without regard to civil service laws, such technical Advisory Committees as deemed appropriate. As a followup on the National Advisory Committees on Aging, the City County Council on Aging was firmly established in the City of Portland, Multnomah County, and on the local level. This Council was formulated on the basis of the criteria established on a national level. It also established the guidelines or criteria upon which a senior citizen program may be established which includes the authorization of an official board. Before amendment of the 01 der American's Act of 1973 is completed, I think it is essential to indicate an overview of the 01 der Americans Act of 1965 up until March of 1973.

STATE AND COMMUNITY PROGRAMS UP UNTIL MARCH OF 1973

First, the principal focus of activity under the Act has been through the comnunity programs conducted under Title III to provide services to older Americans. For example, in 1969 and through 1972 more than one million older persons were served by over 15,000 projects funded under Title III.

Services for independent living were offered in over 300 community programs during 1972. These programs were designed to maintain independent living arrangements for the elderly and assisted in reaching a large portion of elderly shut-ins. Those in-homes and out-of-homes services made it possible for the elderly to maintain a sense of dignity and independence in their own familiar community envi ronment.

In addition, there were approximately 466 community programs on aging which involved other volunteers. These volunteers assisted 
in such services as visiting, telephone reassurance, transportation, teaching adult education courses to other older persons, and delivery of meals and were involved in the planning of community activities and services for the elderly.

Group meals and home delivered meals were provided to $60-70,000$ older persons to help solve nutritional problems of the elderly. This did not include those elderly persons who were receiving food stamps. Many older persons unable to pay received this service without cost. The Loaves and Fishes program is a typical example of the number of programs throughout the nation. In many programs these meals were prepared and delivered by older persons. Senior centers and other community and neighborhood facilities were used for preparing and serving these meals. Some elderly persons were served one meal five days a week. These nutritional programs were specifically funded by Title VII funds. Those elderly who were isolated have benefitted from the delivery of meals to their homes. In analyzing the local programs later on, I will cite more activities that are involved in the local Loaves and Fishes program.

There were 428 projects with transportation as a component or sole service of the program. The Senior Adult Service Center on Union Avenue, Portland, had one of the most effective model transportation programs for the elderly for several years. This program had one or two mini-buses which were radio equipped; cars and other vehicles were used as well. This service enabled older persons to keep doctor appointments, to go to health clinics and food stamp offices, to make trips at a distance, and make visits to senior centers for other significant activities and services. 
There were 337 projects that offered health and health-related services to older persons, providing visiting nurses and in-home health aids to homebound elderly. The health related services offered were health education, geriatric screening and referral, immunization programs, and homemaker services.

With assistance under Title III, state agencies provided support for 623 senior centers which were located in public low rent housing, churches, public and private buildings and/or institutions. These service centers have satellite centers located in neighborhoods where the elderly reside. Satellite centers provided and delivered services tailored to the needs of the elderly in the community. Centers also trained 14,700 elderly for employment and provided opportunities for participation and active engagement in community life (Congressional News 1965). In addition to some of the projects that were functional during this period, the area model project program was first implemented in 1972 with the award of $\$ 2.2$ million to nine state agencies on aging. There were then 21 area-wide model projects in operation, with an average federal cost of about $\$ 32,000$ each. Portland implemented one of those programs through the City-County Commission on Aging.

The characteristics of the elderly recipients of the area-wide model services were essentially the same as those in community grant programs. Projects are multi-service in nature, with five program components. Each program component had been selected as most appropriate in meeting the needs of the elderly in the project area and the mix of services funded is especially tailored to meet their needs. Emphasis was placed on drawing on existing resources in the comnunity. 
One of the best known and most successful programs serviced by older persons was the Foster Grandparent Program. Foster Grandparents provides part-time volunteer opportunities for low income persons age 60 and older to serve children with special needs in institutions on a person-to-person basis. The program was initially developed in 1965 as a cooperative effort between the Office of Economic Opportunity (OEO) and the Administration on Aging to demonstrate the capability and willingness of older persons to make a valuable contribution to their communities. The program was jointly administered by $O E O$ and DHEN until the 01 der Americans Act Amendment of 1969 transferred the Foster Grandparents Program entirely to the DHEW where funding and administration occurred through the Administration on Aging and the regional offices for the Social and Rehabilitation Service. On July 1, 1971, the Foster Grandparents Program was transferred to ACTION, the then newly formed citizen service corps, in accord with the executive reorganization plan \#1 of 1971 .

The Retired Senior Volunteer Program (RSVP) was authorized by the 01 der Americans Act Amendment of 1969. This program provides significant volunteer service opportunities in local communities for persons of retirement age.

RSVP began in 1970 with an appropriation of $\$ 500,000$ and 11 programs. Again, one of those programs was initiated in Portland under the jurisdiction of the City-County Commission on Aging. At the beginning of fiscal year 1972, RSVP was transferred to ACTION under the executive reorganization plan \#1, and the appropriation nationwide was increased to $\$ 15$ million. This funding level has been maintained in fiscal year 1973, and it was anticipated by 
June 1973 there would have been 600 local programs on each state level utilizing 40,000 volunteers. ACTION has also funded 51 two-year state development grants that have enabled the states' offices on aging to provide assistance and support to local Retired Senior Volunteer Programs during this rapid growth period.

\section{NUTRITION PROGRAMS FOR THE ELDERLY}

Public Law 92-258, signed by President Nixon on March 22, 1972 added to the 01der Americans Act a new Title VII, which authorized a nutrition program for the elderly. The purpose of this program was to provide older Americans, particularly those with incomes below the Bureau of Census poverty level, with low cost, nutritionally sound meals served in congregate settings, in strategically located centers. Besides promoting better health among the elderly through improved nutrition, the program was aimed at reducing isolation of old age, and making it possible for them to come together to receive services other than nutritional services for which the program was designed.

Loaves \& Fishes Centers, Inc., in Portland, is currently a benefactor of this particular grant. However, the Loaves \& Fishes program was initiated two years before this grant was approved by the President. Title VII simply permitted the Loaves \& Fishes program to serve larger numbers.

Title VII authorized $\$ 100$ million to maintain the program in 1977, and the President requested that amount for the current fiscal year.

While these accomplishments might sound impressive, in actuality thousands of elderly persons were still not receiving services that 
would prevent them from entering institutions. Hence, in May 1973, President Nixon signed into law an amendment to the 196501 der Americans Act. The amendment specifically provided for the availability of comprehensive programs such as health, education, and social services to elderly citizens who are in need. It also insures that services and resources are coordinated and planned in concert with older citizens, state and local governments, community agencies in addition to the federal government. The signing of this amendment was a direct result of the 1971 white House Conference on Aging for improved services for the elderly. There were numerous advocates or proponents of aging during the White House Conference on Aging (Gray Panthers, Retired Teachers, and numerous organizations) who felt that senior citizens on the whole were by no means getting what they needed in terms of adequate services.

The analysis which preceded the development of the amendment focused on the connection between increasing the purchasing power of older persons and expanding this supply of services which they need.

Some persons believe the connection was a direct one, and that if the incomes of the elderly were substantially increased, they could resolve most of their own problems in the marketplace. That contention is valid only to the extent that the elderly can find in the marketplace those goods and services which they need in the form in which they need them. An examination of the market place does not give much comfort in that regard for those of us who worked very closely with the elderly.

Clearly the demand--both explicit and latent--of older persons for services is and has been high. What has always been missing are 
adequate sources of supply to meet that demand. Augmenting the incomes of the elderly might generate more supply.

Gradually, the analysis arrived at the conclusion that the mechanism called for in the services for the elderly market was a middle man, a broker; a broker would bring buyer (the elderly) and seller (services supplier) together. The function of the service broker, who was frankly described as an individual with highly developed entrepreneurial instincts, would be to use federal dollars. I think Byron D. Gold, who served as a special assistant to Dr. Arthur Flenming, U.S. Commission on Aging, put it very well during a presentation at a conference in April 1973 when he stated that the purposes of a broker are:

1. To concentrate the demand of older persons for services,

2. To search out and, if need be, create sources of supply to meet that demand,

3. To control the quality and cost of services,

4. To assure that information about the availability of services reaches all older persons in an area, not just those who participate or aremobile or literate,

5. To assure that services are accessible and packaged in a form which matches the mix and each individual older person's needs (Perspective on Aging 1973).

In most communities throughout the state of Oregon, and the nation as a whole, the shortage of homemaker services is critical. The provision of such services illustrates how a service broker might carry out his role. A broker would determine in the area for which he was responsible how large the unmet demand for homemaker services 
was. Then he might bring together the community college, the State of Oregon Employment Services, the Welfare Department, and senior centers. The broker would offer to pay the cost of community college or the university for training a fixed number of homemakers who were referred to the college by the employment service and Welfare Department. He would also arrange for the senior center to employ the homemakers by guaranteeing to make up any deficient in the senior center budget caused by the homemaker operation. In return, the senior center would be required to meet certain standards.

Hence, the strategy imbedded in the amendments to Title III and Title VII was to maximize the use of limited federal resources so as to initiate, expand, or otherwise improve the supply of services for older persons. This strategy would have achieved through certain elements:

A. Each state will have divided into a relatively small number of substantial planning and service areas by state agencies on aging (locally called the AAA or the Area Agency on Aging).

B. Certain of the planning and service areas, those carved out by the state agency, and those automatically provided for in the Act, will be designated for the development of area plans on aging.

C. In each of these designated areas, an area planning on aging-the broker will be selected. That agency must (1) establish an office on aging when no such office exists; (2) any office of a unit of general purpose government which is chosen to act on behalf of a, combination of units of general purpose government by the chief elected official of the combination (this is clearly noted in City of Portland Department of Human Resources), or (3) any non-profit agency under 
the supervision for this purpose of the unit or the combination of these units, the general purpose government.

The law gives preference to the selection of the public over a private agency.

D. This agency will use a range of techniques--program development, service facilities, resource mobilization, start-up financing-all to the end of brokering instead of providing services directly for a specific population of older persons, that is, making a market exist according to a reasonable set of rules. So that it can focus on the task of brokering, the area planning agency will be prohibited from providing services directly unless adequate services of supply do not exist and cannot be created.

When the amendment talks of services, it specifically required the provision of only two, information and referral, and/or legal services. However, it is anticipated that as local needs dictate, area plans will address the needs for other services--point-to-point transportation, opportunities for involvement, home repair, homemaker services, mental health services, and adult and basic education to name only a few.

E. An area plan on aging developed by the broker, providers, and most importantly the consumers, which sets forth a strategy for creating a rational services market will serve as the basis for the activities of the area agency. Each state agency on aging will finance both the administrative costs of the area planning agencies, and the cost of facilitating the provision of services.

F. The purpose of Title III of the 01der Americans Act will be limited to the initiation, expansion or improvement of services 
which assist older persons to remain independent.

G. The philosophy of Title III will for the first time emphasize targeting of resources in parts of the elderly population, on specific geographic areas, and on specific services. These provisions were subsequently enacted into law.

Obviously, the implementation of these amendments had several implications, particularly due to the fact that they occurred at the same time the administration of the $01 \mathrm{~d}$ Age Assistance program was being federalized. Among several effects would have been the explicit surfacing in substantial numbers of long unmet needs for services.

The amendments substantially increased the role of local government in delivery of services to the elderly. This change implied a change in the role of state government and volunteer agencies. It was during this particular period in 1973-74 that the City of Portland assumed total responsibility for all aging programs from Multnomah County government. To avoid the possibility of unproductive tensions, the question of what those roles should be probably should have been resolved sooner.

President Nixon's intention to coordinate federal expenditures through the mechanism of area plans bears watching. While the then recentiy conducted project FIND indicated that federal coordination focused on a limited and clearly defined objective in aging was possible, the process being called for in connection with Title III is considerably more complicated.

The amendments demand extensive consumer participation in goal setting and program monitoring. Because many of the older persons who will be the recipients of the services generated by the amendments 
(for example, the disabled elderly) have had difficulty for a variety of reasons articulating their needs, the actual extent to which the amendments disperse central control over service delivery through "deprofessionalization" remains to be seen.

The amendments also call for substates regional planning at the substate level. In most instances of public concern in which such planning has been attempted, it has not proven very successful. Yet the shortage of resources in aging, especially in trained manpower, mandates that planning be attempted at some level beyond the community. Aging planning requires considerably more sophistication in the field of aging than existed at that time. To give an example, the emphasis on targeting requires methods of measuring units of service and target population and for delineating the relative importance of services. There were no such methods readily available to local personnel to utilize them.

Also, a variety of valid criticisms which question whether area planning will function in practice have been raised in several circles. For example, several professionals from various institutions have expressed that (a) no protection to keep the governance of area agencies out of the hands of groups whose interests might be threatened by area planning; (b) the likely unwillingness of area agencies to tackle the difficult objectives in service delivery. (Example: service delivery to minorities and/or non-English speaking persons.) (c) The likely unwillingness of area agencies to target.

Although Title III requires state agencies to assure that quality information and referral services are available to all older persons, its therough implementation remains in doubt. Given existence of 
large numbers of such services provided by the voluntary section and the mandate of the President to the Social Security Administration at the White House Conference to expand its information and referral efforts, it poses the question as to how these elements of the amendments may be implemented. Since all these issues must be resolved, a review of the various functions and powers of organizations and their finance will be discussed in the next chapter in order to ascertain some of the best solutions that have been achieved. 
CHAPTER III

\section{POLITICAL ORGANIZATIONS}

Since the existence of political organizations, pressure or interest groups emerged in order to represent their point of view on the issues, it is not surprising to note the various aging interest groups that came into being during the last fifty years. One of the most dynamic organizations that was established as a pressure group for the elderly and the poor was that of the California Institute on Social Welfare (CISW). According to Philip Selznick, the CISW was organized by a political entrepreneur in 1941 (Pinner et al. 1959). The leader and organizer of that group was George H. McLain, born June 24,1901 . He achieved national notoriety in 1933 when he initially organized an unemployed voters group and ran for mayor of Los Angeles.

The major thrust of the CISW was to advocate legislation in order to increase the old age and medical benefits for elderly and indigent poor as well. Faced with the danger of further losses in his battle to promote new legislation, McLain had increased his efforts to maintain, and if possible, increase his following among the pensioners.

While the California Institute on Social Welfare made some tremendous strides in terms of introducing new legislation for the needy, Mr. McLain felt he would have a greater impact by moving 
to Washington, D.C. in 1954 while the campaign for a $\$ 100$ maximum grant was underway. Shortly after he arrived in Washington, D.C. McLain began to move to broaden the geographic base of his organization. In the same speech in which he announced his move to Washington, D.C., he promised the creation of club houses to pensioners. McLain's preoccupation showed rather clearly through the language he used, "We want to establish this grassroots service for the comfort and interest of the elderly in every community in California" (National Wel fare Advocacy 1955). The first statewide conference of the California Institute on Social Welfare held in Sacramento in 1954 saw the creation of a National Institute on Social Welfare. McLain achieved his result by "merging" the CISW with two other small pension organizations in Oregon and Washington whose "delegates" appeared at the conference.

A second conference styled, "Eleven Western States Conference," took place in Los Angeles on November 4-5, 1955 to promote unified benefits for the elderly poor. According to the leaflet reporting on this conference, the Los Angeles gathering included "pension leaders representing recipients from a complete cross section of the United States." The resolution of the conference was signed by delegates from eight states, most of them western; eight states were "represented by proxy." *

In 1965 when the 01 der Americans Act was approved by Congress, George McLain's organization lost momentum in terms of its advocacy

*The signatures on the resolution were from California, Oregon, Washington, Utah, Idaho, OKlahoma, Ill inois, and Alabama. States represented by proxy were Colorado, North Dakota, Pennsylvania, New York, Massachusetts, and Rhode Island. 
role for the elderly. However, such organizations as the National Council on Aging continued to promote and monitor legislation and programs for the elderly with more sophistication and authority. No longer existed a laissez faire attitude as in the mid-1930's, which one writer indicates "had broken on the economic wheel" (Holtzman 1954).

The Gray Panthers, which was established by Maggie Kuhn in 1974, may go down in history as one of the most influential aging advocates of the elderly. Since its establishment, the national, state, and local impact has been farreaching. For instance, locally, Ron Wyden and Ruth Haefner, co-chairpersons of the local Gray Panthers chapter, have been introducing such legislation as reduction of utility and insurance rates for senior citizens, better housing, accommodations, etc.

There is one important element that has been demonstrated in most of these political organizations, and that is that community integration is an important key to political responsibility. It would suggest that political activities on behalf of the elderly ought to become part of the broader social welfare programs sponsored by groups that have a secure base in the organized community. There is no doubt that if there is to be that kind of integration, there must be a broad consensus regarding the propriety of political action to relieve the aged dependency.

The aged in our society have come to be seen both as an object of and source for political action since the mid-30's. For instance, older persons have been organized in a great variety of social and political groups, and have themselves begun to exert political pressure 
in their own behalf.

As stated previously, the first White House Conference on Aging was held in 1961 to express public concern for the aged through political mechanisms. In the 1960 presidential election, senior citizens for John F. Kennedy, as well as a similar group working on behalf of Richard Nixon, were established as formal political direct action groups. The American Association of Retired Persons, the National Retired Teachers Association, the National Council on the Aging, the Association of Emeriti, all have come into being. Federal programs in virtually every major governmental agency have been directed towards the elderly and their problems. An Administration on Aging in the Department of Health, Education and Welfare was formed. Senior citizens groups have emerged in many locations in the United States, sponsored by cities, churches, unions, fraternal groups, service clubs, etc. In all, we now seem to be living in a period of growing political concern and involvement by and on behalf of the elderly.

The view of political action favoring older persons stems from a social movement involving not only the elderly, but others as well, is the view most often expressed by the political scientist (Cottrell 1960). According to this approach, older people have a great deal of political power by virtue of the fact that in rural areas they constitute a larger portion of the population, and that these rural areas are overrepresented in both the state legislatures and senates. The reasons this potential has never been realized, however, is that the older population is divided among a great many interest groups, most of which do not make the wel fare of the aged their primary goal. If this is true, how did legislation in behalf of older persons 
manage to pass?

To begin with, political organizations, while they were not effective as pressure groups, were effective in making the older persons' plight politically visible. As a result, the cause of the elderly was picked up by unions and political parties. The readiness of various groups interested in the general welfare to commit themselves to programs for the aged was due largely to the existence of large numbers of adult children who were anxious to shift the growing burden of financial support for older people off themselves and onto the government. It is for this reason, as well as the votes the elderly command, that no major political party, trade union or large scale organization dares oppose the income provision of Social Security. It is apparent that older persons themselves have relatively little power qua older people. Some powerful people are old, but they are not powerful because they are old. Most of political power behind programs for older people is generated by others on behalf of older people, rather than by older persons themselves. There are good reasons to expect that this situation will continue to exist. Hence, the role of the older people is generally confined to the local area, unless $s /$ he has been involved in politics steadily throughout his or her life. At the local level, older people may indeed be influential, particularly in close elections or nonpartisan issues, but nationwide politics offer the older person very little in terms of either power or participation. This means that while politics are unique in not demanding disengagement from its older participants, it does not very often offer older people the opportunity to increase in active participation, although more older people may like to. 0lder people 
can increase their efforts to form strong opinions in political affairs, and they can increase their involvement in voting, but unless they have paid their dues in the form of earlier participation in politics, they are not apt to gain access within party organization or government itself.

Thus, in 1965 when Congress passed the 01der Americans Act, it spelled out specific responsibilities and objectives for older people; the establishment of the Administration on Aging was one of the first major results. However, the Federal Council on Aging was by no means dominated by large numbers of elderly persons. In view of this, here is an overview of the various governmental and voluntary organizations since the establishment of an Advisory Committee on 01 der Americans in 1965.

As indicated in Chapter II, the Federal Commission on Aging Committee consisted of a Commission's Chairperson and 15 persons appointed by the Secretary. The selection criteria required appointees to be experienced in or have demonstrated particular interest and special skills in aging as described by the elements of the 01 der Americans Act. Each member of the committee was entitled to hold office for a term of three years. Members of any technical advisory committee appointed under this section of the 01 der Americans Act (Title VI) who were not regular full-time employees of the United States, while attending meetings or conferences of such committees or otherwise engaged in business of such committee, may be entitled to receive compensation at a rate fixed by the Secretary who appointed them, but not exceeding $\$ 75$ per diem including travel time. 
Again, the purpose of the Advisory Committee was to carry out the activities in Title IV, V, and VI as authorized for fiscal year 1966-67, and such sums as Congress may appropriate for the next three years after the Act was approved.

In 1973, the Federal Council on the Aging was established and composed of 15 members appointed by the President with the advice and consent of the Senate of the United States for terms of three years without regard for the provisions of Title VI, U.S. Code. Members shall be appointed so as to be representative of older Americans, national organizations with an interest in aging, business, labor and the general public. At least five members shall be older persons.

Section B I--of the members first appointed, five shall be appointed for one year, five shall be appointed for two years, five shall be appointed for three years, as designated by the President at the time of the appointment.

\section{FUNCTION OF THE COUNCIL}

1. Council shall advise and assist the President on matters relating to special needs of older Americans;

2. Assist the Commissioner in making appraisal of needs required by Section 402 of the 01 der Americans Act;

3. Review and evaluate on a continuing basis federal policies for aging programs, as well as other activities affecting aging. Serve as a spokesperson on behalf of older Americans by making recommendations to the President, via the Secretary, the Commissioner, the Congress with respect to federal policies regarding aging. 
4. Inform the public about problems and needs of aging, in consultation with National Information and Resource Clearinghouse, collecting and disseminating information, conducting or commissioning studies and publishing the results thereof by issuing publications and reports;

5. Provide public forums for discussing and publicizing the problems and needs of aging and obtaining information related to these by conducting public hearings and by conducting or sponsoring conferences, workshops and such meetings.

The Secretary and Commissioner shall make available to the Council such staff information and other assistance as it may require to carry out its activities.

Here is a capsule of the administration of the 01 der Americans Act.

\section{ADMINISTRATION OF THE ACT}

In carrying out the purpose of the act, the commissioner was authorized to (1) provide consultation services and technical assistance to public or nonprofit private organizations; (2) provide shortterm training and technical instructions; (3) conduct research and demonstrations; (4) collect, prepare, publish, and disseminate special educational or informational reports of the projects for which funds were provided under this act; (5) provide staff and other technical assistance through the federal council on aging.

The realities of any major legislation is that there must be a bureaucratic structure in order to implement a legislation such as the 196501 der Americans Act. Without such a structure, it is not 
only impossible to gather substantial information to implement the program effectively, but there is also a hidden problem of not having an official organization to present the facts to the Congress. A good example of what happens when the bureaucratic structure of government does not exist can be seen during the 1930's and $1940^{\prime} \mathrm{s}$ in California; at that time, the Townsend Movement wanted to el iminate poverty in California for senior citizens, but there was no office in Washington, D.C. through which their support could be funneled.

Probably not a single one would receive enough support to make possible a self-contained legislative proposal. This leads to a very fundamental question. Is it better to have low priorities in a system having greater power (a large coalition), or to have high priorities in a system competing for or receiving less than the Federal Commission on Aging.

In reviewing the results of the legislation which led to the 01 der Americans Act, it appears that if success is the measure of good, then low priority in a large coalition is the only hope the elderly have. Their needs ought to be incorporated in general programs to enjoy any real possibility of success. For example, combined transportation needs of older people with those of the handicapped poor did result in gains for both; this is the essence of political coalition.

It is obvious that trained or experienced gerontologists with the cooperation of local governments such as the Commission on Aging and the Area Agency on Aging would have the greatest political impact in terms of formulating policies related to the elderly persons. For instance, he or she has more access to more information about the elderly people than perhaps anyone else, and as a society we are accustomed 
to letting the experts handle our problems. With the Administration on Aging as a base of operations, the government experts in gerontology influenced programs that were being developed in other agencies. Hence, it is advantageous to have the Administration on Aging located in the Department of Health, Education and Welfare, in which the interest of older people would be least represented.

of course, the only difficulty with this system is the fact that in gerontology the so-called "experts" were, in fact, much less expert than the expert in the Department of Finance. There is simply not enough evidence yet for the gerontologist to make many major policy recommendations with full confidence that he knows what is best or what most older people want. This was largely because the layperson or gerontologist does not have or know enough facts or experiences about the changes with age that occur in peoples' values.

Apart from the issue of how programs for the elderly can win political support, there is an equally important issue as to how these programs should be organized and coordinated. The federal government had done, and can do, a reasonable job of providing direct support to older people through programs such as Social Security, ACTION, HEW, etc. Solution of the problems of the elderly cannot be solved just on the national level. The problems must be also based on personal considerations on the local situation. For example, in Multnomah County, in cases where personalized action is required, the local community is the only agent that is capable of doing an effective job.

W. Fred Cottrell has also outlined several important questions regarding the nature of governmental programs (1971). Here are a few of Cottrell's questions: 
1. What should be the official function of the Central Agency of Aging, and what are the relationships with other agencies within the department?

2. What should be the furction of the official Agency on Aging, and where should it be located?

3. What type of agency is needed as a focal point in the community?

4. From where shall it derive its authority and financial support?

5. What is the most desirable method of integrating or interrelating the activities of overall agencies in aging at Federal, State, and Community levels? How can government at each level best maintain working relationships with voluntary organizations, with the private sector of the economy?

6. What should be the division among private and public agencies and organizations?

7. Should government take the initiative in stimulating roles in aging on the part of organizations? If so, what type of organizations?

In order to respond to some of the questions posed by cottrell, here is a synopsis of the Oregon State Program on Aging since the inception or the passing of the 01der Americans Act in 1965.

\section{PURPOSE OF THE OREGON STATE PROGRAM ON AGING}

State Program on Aging exists as a result of the 01der Americans Act of 1965, Public Law 89-73 (July 14, 1965) as amended by Public Law 90-42 (July 1, 1967) and Public Law 91-63 (September 17, 1969) 
and Senate Bill 1163 signed into law March 22, 1972, and as authorized by Chapter 319 of Oregon Laws 1971. Section I(3)H of the latter states that the program and services for the aged shall be administered through the program on aging with the Department of Human Resources.

The requirements of the federal legislation dictate that the state agency on aging carry the responsibility for state-wide planning, coordination of program services, and evaluation on behalf of the elderly population of the state of Oregon. The state program also receives, manages, and administers federal funds which are then allocated as project grants to communities and organizations in the state to provide needed services to the elderly of the area. Local communities must provide required matching funds, either in cash and/or in kind, when awarded a grant.

The goal of the Program on Aging is to assure to the elderly the complete spectrum of services for adequate income maintenance; social involvement and functional roles in every community. To that end, one objective has been to develop within the state those programs and services indicated in assessment of needs, which will el iminate barriers to independent and productive living for Oregon's older population. The program also documents the needs of the state's elderly, as well as consituting an information and referral source on current programs and services as their accessibility to the older person. Although a demographic data and need study of the state's 65 and over population was completed December 1971, this was a continuous process in del ineating gaps in services as the program engages in the effort to coordinate federal, state, and local resources on behalf of older Oregonians who must cope with physical, 
mental, and environmental insults of the aging process.

It is the responsibility of the state program to provide technical assistance and consultation to local communities, agencies and political sutdivisions with respect to the Program on Aging.

\section{ROLE OF THE ADVISORY COMMITTEE}

\section{Federal Law}

The role of the advisory committee to the state agency is not specified in any significantly different manner than currently spelled out in the federal register which is as follows:

The state plan shall provide for the establishment of an advisory committee to the state agency on the implementation of the state plan. At least one-half of the membership of such committee will consist of actual or potential consumers of services under this program, with the remainder being broadly representative of major public and private organizations in the state concerned with the interest of older persons, local government and other persons who are experienced in or have demonstrated particular interest in special needs of the elderly.

\section{Oregon Law}

The Governor's Committee on Aging is created by executive order and has a statutory base.

\section{Overall Duties}

Committee is advisory to the state agency in implementation of the state plan.

\section{Organizations}

While not created by law, the executive director and state programs staff planned to organize the committee in such a manner as to assist the staff in executing the expanding role of the elderly 
program.

1. The chairperson provides leadership to the committee, serves as direct linkage to the governor to the state agency, maintains Tiaison with the Department of Human Resources through its administrator of special services and department director.

2. Secretary--Committee does have an independent secretarj' as the State Program on Aging has provided this support.

3. Sub-Committees

A. Executive Committees--Consist of the chairperson, sub-committee chairperson; meets much more frequently than the scheduled quarterly meetings of the full committee.

B. Technical Review Sub-Committee--This committee reviews applicant proposals for funding and recommends appropriate actions, approved deferment to a later funding or disapproval. A broad base of consultants to this committee is established, including people with expertise in nutrition, protective services for the elderly, health, social planning, housing, etc.

C. Nutrition and Health Sub-Committee--This committee consists of individuals with expertise in this field, such as those who serve on the interagency committee of the cooperative extension service for Oregon State University. It includes professional people in the health and medical fields.

D. In-Service Training Sub-Committee--Consists of individuals skilled in the training of both professionals and 
paraprofessionals to work with older persons in programs statewide.

E. Social Services Sub-Committee--This committee is concerned with development of supportive services for the isolated and low income and frail elderly at highest risk who need in-home services. To maintain independent living and transportation assistance to get to services which cannot be provided in their homes, and social planning.

Here are organizations that are represented on the Commission on Aging.

1. Legislature--One member each from the House and Senate. This is to assist in securing visibility in the legislative branch of the needs of older Oregonians.

2. Adult and Family Services Division--This division for recipient population in adult services are relevant to complete trust of the new amendments.

3. Mental Health Division--The provision of services of the target population of the elderly of highest risk including those with mental impairment, but could be maintained in their own homes with supportive services:

4. Comprehensive Health Planning--Representation from this agency will contribute the knowledge of health services and service delivery system, and relate these health programs to the needs of the elderly.

5. Private Voluntary Agencies--These are agencies that address needs of the aged and those that receive assistance in this task 
through organizations such as UGN or United way (both have concerns and advice regarding state programs that need to be heard).

6. Labor--The work force of Oregon has valid concerns only in the fields of retirement plans, and their own needs and senior family members.

7. Industry--This representation is to reflect the concerns of industry in the field of retirement pensions and retirement planning.

8. Church Related--Recognition of the high significance of spiritual well being for the elderly person, and the existing and potential services that the churches already perform.

9. Representation of Minority Population--Insures that their viewpoints and special concerns in the recommendations and discussions of the committee are aired. Nutrition bill specifies emphasis on developing programs in areas of minority elderly.

10. Higher Education: Gerontology and Social Work Training-This representation is needed to relate to the academic training in gerontology regarding job requirements and programs and services for the elderly.

11. Actual and Potential Consumers of Elderly Services--

A. The elderly themselves,

B. Potential consumers or individuals who represent decisive forces either for governmental polition in the communities, or as Oregon residents as exhibited leadership and involvement in the problems of the elderly. These persons are certainly needed to give consumer perspective and a balance to this service agency representation. 
C. A conmittee membership of 21 is in order and most nearly reflects the increased responsibilities of the State Program on Aging.

D. Prospective individual members of the Committee on Aging represent the interest or organizations under Article III, 1-11, and why each member is especially qualified to represent that interest group.

DEPARTMENT OF OREGON HUMAN RESOURCES ORGANIZATIONS-INTERRELATIONSHIPS AND ROLES

The Department of Human Resources is oryanized in the following manner. The office of the director constitutes the administration unit of the department, responsible for management and coordination of all divisions authorized by Chapter 319 Oregon Laws 1971. Section $\mathrm{I}(3) \mathrm{H}$ of that statute specifies that aging, camps, economic opportunities and the multi-service centers are special programs. Childrens services, corrections, employment, mental health, vocational renabilitation and welfare services are provided through statutory divisions.

The director of Human Resources has specified that the special programs will be headed by the administration. The State Program on Aging, now the Office of Elderly Affairs, therefore, reports to the administrator for general supervision and program coordination. The administrator reviews programs and budget which is developed by the coordinator who is responsible for daily program administration, budget preparation, and execution of the executive order, that 
the coordinator serves as liaison to the governor's committee on aging, carries the appointment authority and responsibility of staff and prepares annual evaluations of employees. The coordinator also resolves internal staff problems and such problems are presented to the administrator if they escalate for required joint resolution. The administrator will review program staff annual evaluations, but is directly responsible for the annual staff evaluations of the program coordinator.

Budget presentations may be made by program coordinator or by the administrator or by the departmental staff. Recommendations to the governor's committee on aging membership are made jointly.

As need and circumstances indicate or warrant, the administrator of the special program division arranges for joint meetings of the Program on Aging Coordinator with the director, deputy director, and other division administrators of the Human Resources Department. In July 1972, the Governor of the State of Oregon's Executive Order \#67-7--Governor's Committee on Aging, in effect stated:

It is hereby ordered and directed that the Governor's Committee on Aging is created for the purpose of serving the State Program on Aging in an advisory capacity in the implementation of its annual state plans on aging which includes nutrition and supportive social services state-wide, under the aegis of integrated service approach, and a comprehensive service delivery system. The committee shall assist the State Program on Aging in maintaining a perspective on the total needs of Oregon's older citizens, and shall advise the Director of the Department of Human Resources and the Governor of those issues which merit priority attention at the State Legislative level.

It is further ordered and directed that the membership of the committee shall include from 16-21 members, including at least two from each Congressional District. At 
least one-half of the membership of such committee shall consist of actual or potential consumers of services under this program, with the remainder being broadly representative of major and private agencies or organizations in the state concerned with the interest of older persons, local government and other persons who are experienced in or have demonstrated particular interest in the special needs of the elderly.

It is further ordered and directed that the Governor shall appoint members for three year terms; its initial appointment made for one, two or three years. The member shall be appointed officio basis.

It is further ordered and directed that the Governor shall designate the chairman. Regular quarterly meetings shall be called by the chairman of the committee, who may al so call additional meetings as needed and circumstances indicate.

It is further ordered and directed that the subcommittee structure of the committee shall be formulated by the Director of the Department of Human Resources in such manner that it can properly address the responsibilities of the State Program on Aging. The services of the coordinator and the staff of the Program on Aging shall be made available to the committee, the committee will file an annual report with the Governor no later than July 31 , one month following the closing of the fiscal year.

In effect, this executive order formulated the basis upon which aging programs will be implemented throughout the State of Oregon.

Once the federal government and the state of Oregon had established the framework of various senior citizen councils, the CityCounty Council on Aging of Portland and Multnomah County officially held their first meeting on March 13, 1967, at which time an Ad Hoc Interim Committee was appointed to study the problems of aging on behalf of the council for aging, and to bring reports back to the joint council. At the following meeting which was held on october 6 , 1967 at 2:00 p.m. at Muttnomah County Court House, the City-County 
Council on Aging of Portland-Multnomah County held their first major meeting with the following objectives: (1). to study the potentials, problems and needs of aging and disseminate; (2) stimulate, encourage and assist in the development of resources, services and activities of aging, and strengthen and/or establish a program or operating agency. More specifically the goals and objectives of the Council on Aging later known as the City-County Commission on Aging in Portland-Multnomah County identified the following objectives:

(A) Develop broad policy goals with the problems of the aged and aging in Portland-Multnomah County; (B) To plan, organize and supervise the administration of programs and service to the aged and aging; (3) To coordinate programs of services for aging in order to minimize duplication; (D) Prepare, publish and disseminate educational material dealing with health and welfare of older people;

(E) Work with the state and federal governments in securing grants to finance program services to the aged; (F) Report and recommend to the City Council and the Board of County Commissioners periodically of status of older people in this community. For more detailed responsibilities of the City-County Commission on Aging, see Appendix II.

As indicated in Chapter I, City-County Commission on Aging in Portland-Mul tnomah County became the first major nonprofit governmental agency that was established for the Administration on Aging. In Chapter IV a review of some programs that became operational will be analyzed in terms of their impact to the elderly population in Multnomah County.

Some projects, referred to as contact centers, demonstrated 
some of the initial success and failures in serving the elderly in Multnomah County. In examining a cross section of the population and services, it was essential to identify a few projects that played a key role in terms of what the services of the elderly are at present. To name a few, Project ABLE (a better life for the elderly, see Appendix III) did some comprehensive planning that served as a model for later projects and services in Multnomah County; the Senior Adult Service Center located in the Model Cities area also played a key role in modeling or demonstrating. Some of the major services that were of primary needs to the elderly were a result of this Center. This project's implementation occurred in April 1971. Project ABLE started implementation in the summer of 1972 . Another project that became operational in the metropolitan area is the Loaves and Fishes program which is basically a nutritional program. The Gresham Senior Center, Northwest Pilot Project, and Foster Grandparent Program are all outstanding projects that were established shortly after the City-County Council on Aging in Portland-Multnomah County. Because of federal and state requirements, those projects were required to develop advisory committees as described in Appendices $B, C$, and $D$. Appendix D covers bylaws.

While the organizational structure of the various councils and/or commissions in addition to advisory committees and boards differ due to administrative responsibility, the bylaws describe fairly accurately the intent of the various projects. The actual results will be analyzed in depth in Chapter IV. 
VOLUNTEER ORGANIZATIONS OF THE ELDERLY PERSONS

As increased awareness of older peoples' problems has come to the general public's attention, voluntary organizations have responded to the need in an ever-increasing number.

The emphasis was placed in two directions, namely, local volunteers organization involvement by elderly persons themselves through golden age clubs and senior citizen centers, followed by national organizations, both for older persons themselves, as well as to some elderly exclusively or importantly.

Local or community based efforts are, for the purposes of this section, confined to involvement by elderly people themselves in golden age clubs and senior centers.

In reviewing the purpose of a couple of golden age clubs in Multnomah County, it appears there are numerous purposes for these clubs. They are designed to offer opportunity to make new friends, to form new hobbies, develop new interest to mix with people interested in one's self, to serve other people for a host of reasons. In short, it is geared to providing a purpose for living in the retirement years. The term golden age club has come to refer to a group of older people who have banded together in a formal organization, self-sponsored or sponsored by a public or private agency or organization, for the purpose of a social outlet. My observations suggest that the majority of the members usually are aged 65-70 years. This is in contrast to the age group of homes for the elderly residents who usually are in their middle $70^{\prime} \mathrm{s}$, and that of the nursing homes where the late $70^{\prime} \mathrm{s}$ and $80^{\prime} \mathrm{s}$ can be found to predominate. 
There are numerous national organizations that are not only supportive to the local senior service centers or organizations, they have also set up a framework that permits the local senior center organizations to be more effective in the implementation of services to the elderly. Here is a sample of some of those organizations.

One of the most significant contributors to the national scene is the Gerontological Society, Inc., which is a society devoted to researching aging. This is a nonprofit national organization, founded in 1945 to improve the well being of older people by promoting scientific study of the aging process, by publishing information about aging and by bringing together groups that are interested in research training and elevation of services to older people. The professional sections consist of Biological Sciences, Clinical Medicine, Psychological and Social Sciences, and Social Welfare.

The National Council on the Aging is the leading national voluntary agency providing professional services for organizations and individuals concerned with the field of aging. It is nongovernmental, nonprofit and tax exempt. It has developed standards and materials to help people do a better job for the elderly in areas of employment, preparation for retirement, health, housing, institutional care, community services, education, leisure time and community planning and development. It offers information consultation resources including the most comprehensive library in the field of aging; it provides field service when requested; it offers its members a regular library bulletin and the National Council on Aging bulletin; undertakes research and studies; it sponsors and incorporates symposia; and it is published exclusively among other services (National Council 
on the Aging 1968).

The National Council on the Aging was first organized at the request of community leaders, civic groups, government agencies, and others as a result of the great need for professional advice and information in the field of aging. It has provided services on a continuing basis since 1950. The National Council on Aging has been a meaningful contribution to the achievement of better housing, and significant leisure time, activities, better family relationships, more community services and a life of dignity and respect. As a former director of a senior citizens project in Portland, I can attest to the profound consultation that was received from staff members of the National Council on the Aging, whose west coast office is located in San Francisco.

The National Council for Homemaker Services was incorporated in 1962 to stimulate the expansion and promote the improvement of homemaker services throughout the country; membership is open to agencies providing homemaker services, and to organizations and individuals interested in promoting the council's purpose. Working cooperatively with the other national health and welfare organizations and with public and voluntary agencies, the council:

1. Promotes understanding of values in homemaker services.

2. Provides the central source of information and medium through which knowledge and experience can be pooled and made available.

3. Encourages and guides communities in organizing and extending homemaker programs.

4. Promotes development of standards. 
5. Publishes reports and distributes educational and promotional material; sponsors conferences and seminars (National Council for Homemaker Services 1964).

Homemaker services for the elderly are a prime focus to the national council, especially because it is one of those services that plays such a vital role in older people staying in their own homes as long as physically possible. This service prevents premature institutionalization of many elderly persons.

While there are numerous other important national and local voluntary and nonprofit organizations, it is my opinion that the few described earlier is a representative sample of the many outstanding voluntary organizations.

Although the various councils, commissions, and advisory committees achieved significant results, they encountered many problems during early organization of the elderly programs on the local level.

Among the myriad problems that the various advisory boards, councils on aging, etc., were faced with was the inability to come to a consensus as to the major problems that exist in aging. For example, in reviewing the minutes of October $6,1967,2: 30$ p.m., at which time Mayor Terry Schrunk was presiding over commissioners of both city and county, as well as various persons from a number of organizations and walks of life in the community, it was clearly obvious that some committee members were entirely interested in high costs of nursing homes, while others were more interested in higher retirement income, lower cost housing, employment, and transportation of the elderly. It was also obvious that some comrittee members, including some commissioners, were not even in favor of the 
City-County Council on Aging organization. For instance, one commissioner felt the elderly could be serviced at a lower cost with the existing social agencies within the community (Public Welfare, Employment Division, churches, etc.). There were also division among the various groups as to whether the advisory council or committees should promote direct services versus recreational services throughout the neighborhoods. For example, according to the minutes, Gershon F. Goldsmith, an attorney, testified:

We have heard that in some other communities, community actions have resulted in low cost theatre tickets and other types of public entertainments for the elderly. I have recollection of that in London. 01der people are entitled to theatre tickets, pensioners for no cost. (City-County Coordinating Committee 1967)

Mr. Goldsmith went on to say that he thought this would be an appropriate subject to explore in Portland, so that older persons would have some utilization of their time, and possibly theatre owners would be able to fill up their theatres during lower usage of theatre times. Another problem that faced the advisory council and committee was the inability to agree on the types of senior centers that may be established. For example, some member had envisioned establishing multiservice centers with a diversified number of services and activities. There were some members who felt the need to have drop-in senior centers for a few hours during the day. There were also those members of the committee who felt they should have addressed such needs as day care needs for the elderly. For example, he said, One major function of the drop-in center is to provide one telephone number where one older person with a problem can call and get an answer; just as importantly, where the children of older people who have problems can call up and get an answer. The elderly would call the Community Council 
they would call various places where people have fragmentary answers, and one hopes to be able to service telephone requests. (City-County Coordinating Committee 1967)

There were apprehensions by various members of the Advisory

Council and committees as to the possibilities for aging projects.

In order to demonstrate some of their concerns, here are excerpts

from some of the minutes taken on 0ctober 6, 1967.

Some of you may say, well it's just the same as federal funds or city or county funds; we are spending taxpayers' money. There is some merit to that. On the other hand, if funds are appropriated by the federal government to go to the State Program on Aging and that they are not spent for such as we are talking about, the State Program on Aging is not going to turn around and give those monies back to the federal government; in fact, they have had more grant applications than they have approved. So what it would mean, if you decide you don't want to go ahead on this program, is that these available funds would be used in other state programs, presumably not in Multnomah county.

One very important point I would emphasize, we do not approach this information and referral center with a dogmatic attitude. We are still trying to find out what this community needs. We use the information and referral center as not only an end in itself, but as a tool to help us determine what the city and county should provide for the elderly. It is possible that we will find that there is not a need for an information and referral center. We have been advised by experts that there is such a need, but I assure you of one thing; in our experience with the center, we find that there is not a substantial community need, we would be the first people to come to you and say, we are going to abandon the center.

Now I would like to say a few words about the status of our grant application. A grant application has been approved, and you have a copy of it in your folders, by the State Program on Aging, it has sat for many weeks in the governor's office, because now, by some arrangement between the governor's office and the state program on aging, all programs for which funding approval granted must be approved by the governor's office.

Bear in mind we do not have a budget outside the center, we have not budgeted for personnel to staff our agency other than as set forth in this program that you have here. 
There is a greater doubt, I should tell you in all candor, about getting the federal funds for this program. The federal funds for all State Programs on Aging, including the programs that have been approved, that were not approved prior to July 1, 1967, are coming out of the 1968 fiscal year Health, Education and Wel fare appropriation. The latest word that I have on this appropriation measure--and Senator Morse's office checked with Washington around noon for me--was that al though the money was authorized in Health, Education and Welfare bill amending the 01 der Americans Act, and was appropriated by the senate, that it was in the Senate House Conference Committee, and was reported back to the house floor and the House returned it to the House Committee; so there is some question at the moment whether the funds will be appropriated for any program on aging that is funded in Oregon, including this program.

At the outset of the Council on Aging Meetings, as well as the various advisory board meetings within the various neighborhoods, several citizens felt that the establishment of a council on aging or senior citizen center would be a duplication of services already being provided in Multnomah County by an existing 65-85 social agency. Some citizens also felt such programs would drastically increase their property taxes, yet they would not receive tangible services from these centers or programs. (City-County Coordinating Committee 1967)

There were many positive outcomes from these meetings, however. The Portland City Council and Multnomah County Board of Commissioners jointly approved the establishment of the City-County Council on Aging (now known as the City-County Commission on Aging). At a later date, it was also jointly funded by both public organizations with equal authority of selecting members at large from the community to carry out its function. Secondly, the councils and various advisory committees began to address specific social services and some prior orders. For example, such recommendations came out from the committees as income assistance, counselling, senior centers, foster grandparent programs, protective services, handyman services, outreach services, etc. 
Once the City-County Council on Aging in Portland-Multnomah County was established, there were rapid development of various programs or projects within the metropolitan area during the next three or four years. For example, the Gresham Senior Adult Service Center was established; this is a program which initially provided social activities for senior citizens. The establishment of the Loaves \& Fishes Program came into existence, as well as the senior community program, the Senior Adult Service Center, Project ABLE, Northwest Pilot Project, Friendly House, Southeast PACT Senior Center, Montavilla Senior Center, etc. Most of these programs were directly or indirectly a spinoff of the formation of the City-County Council on Aging.

As provided by the federal guidelines, a program must establish or develop an advisory board or a council as delineated in Appendices III and IV. Therefore, the project director always worked very closely with the advisory boards in order to achieve the objective of the senior citizen programs. The project director was responsible to assure that the staff carried out the agreed directives of the program within the purview of the agency.

Financing--when the Federal Council on Aging was established by the consent of the Senate, it was the intent that the state and local (city and county) will also proceed to develop and implement programs under the same design. That is, the community had a responsibility to establish aging councils and commissions in addition to advisory committees.

Specifically, the local community was mandated to establish an advisory committee who could be responsible for developing senior 
center policies and programs. They might be the sponsoring groups, or one of the initial groups could act as a sponsor, such as the City of Portland-Multnomah County Council on Aging in 1968. The membership in the advisory group had to reflect a broad representation in the community. It had to be comprised of senior citizens, people from the clergy, business, labor, education, public welfare, health and social groups, etc. The role of the advisory council or committee should be supportive rather than managerial. In other words, the advisory council or committee should be responsible to (1) undertake a community relation and policy program to acqua int senior citizens of such a project and generate community interest and support, testing out the plan at community meetings of older people; (2) to assist in making a decision on sites in establishing a center or senior center program; (3) prepare preliminary programs for the senior centers.

In analyzing at least nine advisory boards and/or Commission on Aging in Portland-Multnomah County, most members of these boards were volunteers. About four years ago, I noted that members of two advisory boards in Multnomah County were eligible for a $\$ 15$ a month stipend if they attended meetings on a monthly basis, and they chose. to accept the stipend. With the exception of those two projects, all other boards that I have attended or investigated have members serving in a voluntary capacity.

I have al so noted that many of the projects' advisory boards tax themselves with monthly or annual dues in order to provide special projects to other senior citizens as well. With respect to these voluntary organizations, participation can be characterized 
by an active minority which controls the organization and an inactive majority which participates occasionally in activities or is sometimes apathetic. Perhaps Lord Bryce stated it best when he said that voluntary associations were an important component of American democracy, recognizing the "near-universality of minority rule in all assemblies and groups and organized bodies of men..." (Bryce 1921).

Philip Selznick has also described some typical voluntary tendencies that were observed in many of the advisory boards or council meetings that I have attended. Selznick described it in the following manner:

Most voluntary associations...are skeletal in the sense that they are manned by a small core of individuals--the administration, the local sub-leaders, a few faithful meeting goers--around whom there fluctuates a loosely bound mass of dues-payers. This type of membership has, on the whole, only a very limited relationship to the organization; its agreement with it (maybe of the vague sort); it may give little or no time to the organization, nor be guided by its pronouncements save, as in unions and professional groups, on very narrow issues; in short, the power implications of memberships are minimal (Selznick 1952).

However, contemporary characteristics of the aged give indications of their changed position in the society as compared to the society in the past and present. Greater free time in our society is coming at a point of longer life, better health, reduced economic pressure and an earlier age of retirement for more and more old people. For most, it is no longer possible to work at their jobs with progressively decreasing work hours. Unless they moved into a second job at retirement, retirement is then complete. With more free time, elderly people are theoretically more able to participate in voluntary 
associations than younger people--although free time, that is time away from one's job, is increasing for all age groups. In attending many of the various board meetings in Multnomah County, it was noted that most of the board members were former professional persons, hence, had larger retirement incomes than most of their peers.

In determining sources of many of the senior citizen advisory boards and commissions, I have noted that the City and County of Portland-Multnomah have been funding the City-County Commission on Aging since its conception in 1968. Most of the other voluntary organizations receive donations from various funding organizations, such as foundations, churches, social and private clubs, Jaycees, Volunteers of America, Salvation Army, etc. These organizations provide major funding that assist the advisory committees and boards to sponsor special projects for the elderly.

Prior to 1966-68, senior citizens centers were usually operated as private nonprofit corporations under the auspices of churches or the Salvation Army; often with United Fund money as well. It was noted that there were several hundred senior centers, and those organizations usually constituted the sole community attempt to offer recreational and educational programs for older people. In assessing the impact of the 01 der Americans Act of 1965 upon senior citizens In Portland and Multnomah County, and measuring its effectiveness, the small group of older people who utilized those senior citizens services prior to 1968 would seem to indicate that they did not constitute a viable alternative for recreation and education among the overwhelming majority of other persons. 
of course, many elderly who might have otherwise used the senior centers' facilities were prevented by difficulties of access--poor transportation, disability, health, etc. Yet even in communities where all out efforts have been made with the resources they had available at that time, only a small minority took advantage of them due to a lack of dependable services.

Senior citizens programs reflected the needs of the members of the elderly population, along with suggestions with advisory committees. In summary, the senior citizens programs reflected a place where the elderly could find companionship, learn skills, receive personal services, find opportunities for self-expression and social action. 
CHAPTER IV

SOME SPECIFIC TYPES OF IMPACTS OF THE OLDER AMERICANS ACT IN PORTLAND-MULTNOMAH AREA

In order to determine the specific types of impacts the 01 der Americans Act of 1965 had on the Portland-i1ultnomah County metropolitan area, it was necessary to take an inventory of the services that were being provided senior citizens prior to the passage of the Act. It was also necessary to determine the types of funding, amount of funds, and the demographic factors that existed in Portland in the early 1960 's and to what extent those factors have changed up to this point in time. The bases of my findings have been combined over the past four years' studies. As a former director of the first model service program in the City of Portland, the question as to whether the services were making any impact upon the recipients of the services was always a key question in my mind. Hence, the findings reflected were based upon (a) my personal interviews with one hundred seventeen recipients of specific elderly services since 1969 in Portland-Multnomah County, and (b) discussions with several directors and/or managers of senior citizen service sites, and (c) analysis of numerous quarterly and/or annual reports, and (d) my personal assessment, analyses and observations while working directly with the elderly since 1971. These observations included numerous meetings, not only in Portland, but throughout the state of Oregon and West Coast, as well as submitting various budget proposals for elderly 
programs before a number of funding sources. These findings are also a reflection of the feedback I have received from some advocate organizations such as the Gray Panthers, the City-County Commission on Aging, the Montavilla Senior Center, and members of various elderly citizens advisory boards.

Interviews that were conducted with senior citizens in terms of their satisfaction with services provided by service centers were accomplished in a very personalized fashion; specifically, there were no formal questionnaires at all during my conversation with the elderly recipients. Reasons for not pursuing this study in that manner were perhaps described by an article in The Oregonian (March 30, 1977) which stated:

A cartoon we saw recently shows a young man with a large notepad and questionnaire standing next to an elderly woman in the open doorway of the woman's home. The woman, who was frail and poorly dressed, says to the young man, who is writing furiously--Sure I have enough money; of course, I am not lonely. Why should I worry about my health? Who is afraid of crime? Why are you so nosey? This cartoon represents the worst in aging research-prime questioners, pushy stereotypers and basic insensitivity--and we think the senior citizens subjected to such questioning should feel free to slam the door in their questioners faces.

Hence, my conversational approach to the interviews which were conducted reflects more of an interpersonal feeling of the persons interviewed. Basically, the conversations or interviews specifically addressed such areas as:

1. Consumer satisfaction with services received through elderly programs.

2. Types of services that they were receiving.

3. The manner in which services were delivered to the elderly. 
For example, were they adequate; did they meet their needs? If they were not satisfied with the services, did they have recourse to have their complaint addressed and corrected?

4. How does the quality of service differ in the last five years versus 1969 ?

5. Did many of the organizational leaders think senior citizens felt that the present services were meeting the needs of the elderly clientele?

6. How could the services be improved?

7. Did they feel city and county were addressing the needs of the elderly? If so, are they satisfactory, poor, good, outstanding, or need improvement?

8. What does the future hold in terms of providing adequate, efficient, and effective services for the elderly?

INVENTORY OF ELDERLY SERVICES PRIOR TO 1965

CITY OF PORTLAND-MULTNOMAH COUNTY

In reviewing the services that were available to senior citizens in Portland-Multnomah County prior to 1965 , it was evident that there were no exclusive services to the elderly population prior to 1965. The services that were available to senior citizens before this time were incorporated in other governmental or social services for all persons. For instance, the Public Welfare Division provided the major source of income for the elderly through old age assistance. However, senior citizens were not served exclusively at that time. This was al so true of Social Security, whereby the senior citizens were served, as well as the handicapped and/or children that were eligible within 
the framework of the Social Security Act. There were absolutely no employment services for the elderly prior to 1965. Other services that were available were very sporadic; they were usually provided through some of the churches or private clubs as described in the previous chapter. In examining the minutes of the City-County Coordinating Committee, October 6, 1967, Mayor Schrunk emphasized that one of the major reasons for the need to form a City-County Council on Aging was to formulate and address the needs of the elderly through a formal structure, such as the Council on Aging. The Council first addressed the development of drop-in centers for the elderly, service sites for the elderly, research, etc. Since passage of the 1965 01 der Americans Act, several programs were established and implemented-some of which are still operational.

While there are at least eight service sites in Portland-Multnomah County metropolitan area, and at least 25 Loaves and Fishes Centers (meal sites), in addition to at least six drop-in centers, this analysis will only include a sampling of all service centers within the PortlandMultnomah service area. Those programs or projects include the Senior Adult Service Center in Model Cities, Loaves \& Fishes, Inc., the Gresham Senior Center, the Northwest Pilot Program, the Foster Grandparent Program, and Project ABLE (now defunct).

\section{DEMOGRAPHIC CHARACTERISTICS OF ELDERLY NEEDS}

PORTLAND-MULTNOMAH COUNTY 1968-1975

The elderly poor are perhaps the only group in our society for which poverty is an increasing condition, although some current trends may differ. Problems of income, poor housing, high rate of unemployment, 
inadequate transportation and health services, etc.--problems that affect all low income groups--are more acute for the elderly poor. The fact is, the elderly person remains at a fixed income level despite the pressures of inflation and ever-increasing taxes. The aged neither buy nor spend much on consumer goods; but, they do spend proportionately more of their income for necessities like medication than any other group. The potential for illness is three times higher than younger persons, yet less than one-half these expenses are covered under Medicare. Spiraling property taxes can turn home ownership into a liability.

The number of elderly Americans (those over 65 years of age) shows a net increase of 1000 per day. It is estimated that by the year 2000 , more than 29 million Americans will be 65 or older...one in every nine persons. At present, one in every four Americans are poor. For a composite of Project ABLE's impact analysis, see Table I. Nationally, the 7.5 million widows and single women are the poorest segment of our society, because of either life-long dependency on husband's income, or because women's salaries have generally been up to 60 percent lower than men's salaries.

In order to develop a standardized allocation of funds that can be utilized to achieve an equitable distribution of resources, it was necessary to determine geographic distribution of elderly needs in Portland-Multnomah County. To achieve this, a study of the geographic characteristics of elderly persons in this specific area was conducted during the planning process, which extended from 1969 to the present, on an annual basis. The purpose of the study was threefold: to 
TABLE I

PROJECT ABLE IMPACT ANALYSIS

PERCENTAGE COMPARISONS OF

THE ELDERLY

Mul tnomah

State of County Oregon United States

Total Population

Over 65 Years $70,515 \quad 226,000$ $20,101,874$

Age Group:

65-74 years

$57 \%$

$60 \%$

$62 \%$

75 yearst

$43 \%$

$40 \%$

$38 \%$

Sex:

Male

$40 \%$

$44 \%$

$43 \%$

Female

$60 \%$

$56 \%$

$57 \%$

Living Arrangement:

19761009,1500

\begin{tabular}{|c|c|c|c|}
\hline 23,267 & $33 \%$ & $28 \%$ & $37 \%$ \\
\hline w/Spouse $\quad 25,258$ & $50 \%$ & $56 \%$ & $50 \%$ \\
\hline 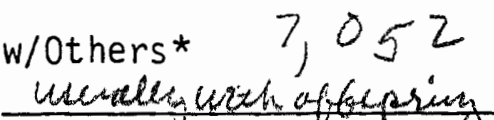 & $10 \%$ & $9 \%$ & $+92 \% 13$ \\
\hline $\begin{array}{l}\text { malctubure, barang } \\
\text { Income: }\end{array}$ & $\begin{array}{r}43 \\
7\end{array}$ & $\begin{array}{l}3 \\
7\end{array}$ & 100 \\
\hline Below Poverty Level & $25 \%$ & $25 \%$ & $25 \%$ \\
\hline
\end{tabular}

Source: Oregon Governor's Committee on Aging, 0lder Oregonians' Universe, 1974. Facts on Older Oregonians N.P.N.D.

*Does not include those in hospitals and nursing homes. 
develop a profile of the characteristics of the elderly population in Multnomah County; to obtain better estimates of the needs of the elderly living in Portland-Multnomah County; to provide a basis for geographic distribution service dollars on an annual basis.

National and local studies have shown a correlation between certain demographic characteristics and institutionalization. Since the primary goal of the aging-service system is to assist the elderly person to sustain independent living and utilize the available services on a maximum basis, demographic characteristics which have been correlated with the risk of institutionalization were shown as indicatory of need. These needs are briefly described.

1. Number of persons 60 years or older. The population over 60 represents the general target population for the present Area Agency on Aging. The distribution of persons over age 60 in PortlandMultnomah County provides a basic framework for the determination of needs.

2. Number of persons 65 years of age and older, with income below poverty level. According to the 1970 Project find report, three out of every ten persons over the age of 65 are likely to be in poverty, compared to one person out of nine for younger persons; 31.8 percent of the elderly population in Portland-Multnomah County have incomes below 125 percent of the poverty level (less than $\$ 200$ per month). According to the 1970 census, of the persons identified by Project ABLE as being at high risk of institutionalization, 36 percent had incomes of less than $\$ 100$ per month, and another 52 percent had incomes between $\$ 150-\$ 250$ per month (1973 evaluation report). Poverty is a strong indicator of need for services in the elderly population. 
3. Number of persons over age 75. Fifty-six percent of the elderly persons identified by Project $A B L E$ as being at high risk of being institutionalized were over 75 years. This compares to 31 percent of the elderly population over age 75 in Multnomah County. Persons over age 75 tend to be poorer than the general elderly population. Seventy percent of the elderly population identified as being in poverty by Project Find were over age 70. According to 1970 census data, the average income for males over 75 was $\$ 3449$ per year, and for females over age 75 was $\$ 2055$ per year. (The average income for males between the ages of 60-69was $\$ 6672$ per year; for females in the same age range, the average income per yearwas \$2947.) Increased age, then, is often an indicator of poverty and increases a likelihood of substandard services.

4. Number of minority persons 65 years and 01 der. llost of the elderly minorities in Portland-Multnomah are residing in the northeast section of Portland, which happens to be the location of the Senior Adult Service Center Program. Elderiy minority persons are a federal priority population for Area Agency on Aging services.

01 der minority persons are twice as likely to be poor as are older Caucasians. The mortality rate for older minority women is twice as great, while ten percent higher for older minority men. Eleven percent of older minority persons are likely to be without living kin, compared to six percent of older Caucasians (multiple hazards of race and age). Twenty-eight percent of elderly persons identified as being in poverty by Project Find were of a minority race, while eight percent of the eldery population was comprised of 
minority persons. Project Find reported that 85 percent of 01 der minority women who live alone are in poverty.

National studies indicate that older minority persons are less likely to be aware of existing resources. One such study concluded: to be old and a minority is to be at double jeopardy.

The distribution of elderly minority persons in Portlandfultnomah County, then, provides another indication of need for subsidized services.

5. Number of persons 65 plus in group facilities (other than institutions). Project ABLE found that rooming houses and hotels were often stepping stones to institutions for elderly people. Less than one percent of the elderly in our area lived in group facilities other than institutions. Twenty-four percent of Project ABLE's clients who were institutionalized were in group facilities prior to their institutionalization. Ten percent of Project ABLE's high risk groups were living in rooming houses.

Living arrangements in rooming houses and hotels often provided inadequate kitchen facilities, making it difficult for the elderly to prepare adequate meals for themselves; the number of elderly in group facilities other than institutions, then, provides another need for subsidized services.

These basic six demographic indicators described above were compiled from 1970 census data for the 153 census tracts in PortlandMultnomah County. The composite of the indicators provided shows the extent of need in such census tracts; these needs were utilized as the standard allocation formula for distribution of some aging service dollars. 


\section{DEVELOPMENT AND EXPANSION OF AGING SERVICES}

IN PORTLAND-MULTNOHAH COUNTY

As indicated previously, most aging projects in Portland-Multnomah County since 1968 were directly or indirectly spin-off programs the City-County Commission on Aging (formally known as the CityCounty Council on Aging). Here is a recapitulation of the services in Multnomah County. The Commission on Aging was established in 1968 as a joint agency between the City of Portland and Multnomah County. As reflected by its bylaws, its main function was to plan and develop new programs, in addition to coordinating existing services for senior adults. During fiscal year 1973, for instance, the Commission on Aging planned and received $\$ 850,000$ in federal funding for major programs, which included the Senior Community Service Program, Retired Senior Volunteer Program (RSVP), Senior Adult Service Center and Project ABLE. Services in all programs were subcontracted through existing organizations.

1. The Senior Adult Service Center--the Center began on April 14, 1970, when a committee for older adults, a subcommittee of Model Cities Social Services, was established. This subcommittee composed entirely of older liodel Neighborhood residents worked with the City-County Commission on Aging's staff on program development. Because the 37-member subcommittee was too large to function efficiently, an executive committee of thirteen elected persons was established. This committee worked directly with the Commission on Aging on program planning.

In order to designate the primary concernsof the elderly, a 
questionnaire was circulated. This questionnaire revealed they were concerned about home visits, shut-ins and persons living alone, phone calling, personal services, etc. They were also concerned with increased monthly income, assistance in defraying drug costs, transportation, minor home repairs and telephone reassurance.

Guided by the needs of over 800 respondents, the Senior Adult Service Center was established. At the outset of the implementation stage in 1971, there were 45 part-time elderly persons employed, in addition to ten full-time persons. In 1974 when this, information was obtained, the Center employed 25 elderly persons and nine full-time persons. Since Apri1 1971, the Center has been serving over 1900 senior citizens per year. Thus, the program has been fulfilling a two fold goal of employing senior citizens to assist those senior citizens who are unable to help themselves. Subsequently, elderly employees are able to supplement their meager retirement incomes, and the recipients are able to lead normaj lives in their own homes. The Senior Adult Service Center was providing the following five major services exclusively to the elderiy within that service area:

Qutreach Component employed 1.4 senior citizens, who provided companionship and limited household assistance for at least 288 persons per month, who were handicapped and/or living alone.

Telephone Reassurance Component employed three older ilodel City Residents who, on a daity basis, telephoned over 125 senior citizens to check on their well being. This service has inadvertently saved the lives of some of their friends. On a few occasions these persons fell in their homes and were unable to obtain assistance until the telephoner summoned a law officer to check their homes. 
Handyman Component employed five retired handymen who served an average of 45 senior citizens per month by completing an average of 70 minor home repairs. These household repairs included mending broken windows, fixing leaky faucets, repairing broken steps, repairing broken door latches, plus completing myriad miscellaneous chores.

Transportation Component employed two part-time and three ful1time senior citizens and served at least 1200-1300 riders per month. This portal-to-portal service transported seniors to doctors, grocery stores, banks and to cormunity social functions. The cost of cab fare or the inability to ride city buses prohibited many senior citizens from taking part in daily activities. This service, like others mentioned, was provided without charge to the elderly.

Information and Referral had al so become a vital part of "the total service program" for senior citizens. When the Center was unable to provide a particular service, referrals were made to other sources. See Appendix $C$ for a typical referral list.

In addition to the necessary services provided by the Center, it also sponsored a monthly meeting-potluck at the Matt Dishman Community Center. Speakers from different organizations or comunity agencies were invited to speak about the services they offered that were pertinent to senior citizens (Housing Authority, Welfare, Social Security, etc.). The Center published a monthly newsletter, "The Star," which informed over 1000 elderly residents (per month) of services provided to them. The Center conducted and encouraged quilting andarts and crafts sessions on a weekly basis, while maintaining a general open door policy where friends could meet and enjoy each others' company. 
The Senior Adult Service Center was funded by the Housing and Urban Development Department via the Model Cities Project until the end of the 1975 fiscal year. The intent of such a program was to demonstrate or model successes of the project in order that successful components or centers could be implemented throughout the city, county and state at a later date. In reviewing records of the Senior Adult Service Ceriter, it was funded at an average of $\$ 171,000$ per year for the. first four years of its existence.

of the 117 seniors interviewed, 62 received services from the Senior Adult Service Center. Some of the typical responses from the recipients were:

For the first time in our lives, we actually received services that were promised to us.

I hope we may continue to receive such outstanding services indefinitely.

I am no longer afraid to go to the bank or store since the door-to-door transportation service serves as a protective measure.

Only four of the service recipients reflected any negative sentiments or negative responses as to the services the Center provided. Those four seniors felt they were not receiving "their fair share of the services provided by the Center." For example, one elderly person indicated that the transportation services were only given to her three times per week. While the recipients of services provided by the Center were extremely enthusiastic and grateful, some, approximately $50 \%$, were apprehensive about the continuation of the services after 1975. 
2. Project ABLE (A Better Life for the Elderly)--This project began in 1972 as an area-wide demonstration project in Multnomah County. Project ABLE was one of the many projects operated by the CityCounty Commission on Aging. The project's objective was to alleviate major problems threatening the capacity of older adults to live independently in the community. It sought alternatives for institutional care for the elderly population in Multnomah County. A comprehensive service system with six components (Transportation, Nutrition, Homemaking, Counseling and Information, Legal Assistance, and Protective Services) was provided to meet that objective. The Project aimed to help people who were 60 years and older with low incomes. During the 1972-73 fiscal year, 2700 elderly persons were interviewed, of which 2100 continued to receive services through fiscal year 1974. Those clients generated almost 3000 referrals to contracted ABLE services; and another 4400 referrals to other community programs. While Project ABLE was phased out at the end of fiscal year 1974, the Project not only provided some vital services to many elderly persons but also established a broader base on which future services were being implemented more effectively and efficiently to senior citizens in Multnomah County.

3. Loaves \& Fishes, a non-profit corporation, provides nutritious meals at noon to people over 60 years of age at 26 centers throughout Multnomah County, five days per week. For the vast majority of our society, eating and socializing are synonymous. Millions of elderly persons are compelled to eat alone due to loss of spouses, familiar neighbors, and friends. Hence, eating alone constantly can, for the most part, turn eating into a very lonely or dreary experience that 
ultimately dampens the appetite. It has also been noted that it could effectively eliminate most incentive for preparing nutritious wellrounded meals. Those who must eat alone know full well how much easier, convenient and quicker it is just to eat from a can. Moreover, those senior citizens who are plagued by having no dentures, or 111 fitting ones, will simply eat soft foods--bread soaked in milk, soups, and other liquids. Consequently, when Loaves \& Fishes began in 1970, it was received exceptionally well.

On February 9, 1970, the first Loaves \& Fishes meal was served to a small group of 01 der persons at Lincoln Street Methodist Church in southeast Portland. The idea was the brain child of a few concerned women. They had hoped to provide a well-balanced noontime meal in the company of friends and neighbors to fill some of the lagging nutritional and social needs of Portland's increasing population of older persons. They enlisted the support of churches and community groups in the area which could furnish the necessary kitchen and dining room facilities, and most of all, the volunteer talent so important to the success of such a great undertaking.

In 1978, Loaves \& Fishes, Inc. became Loaves and Fishes Centers, Inc. It is apparent a "neighbors sharing with neighbors" philosophy can work the same kind of multiplying miracle as listed in the biblical story of the loaves and fishes, or a more contemporary version of Good News puts it--"We Have Come a Long Way."

Loaves \& Fishes program serves approximately 12,000 monthly meals among 26 centers in Multnomah County (Loaves \& Fishes 1973). Based on information received from the director of that project, this does not include the number of meals provided by the project 
in other neighboring counties, such as Washington County. However, those meals are inclusive of the Meals on wheels that are delivered by volunteer carriers to homebound recipients.

It is estimated there are more than 3000 volunteer workers, half of whom are elderly participants themselves. Facilities, financial support, and volunteer help are provided by about 260 churches and congregations, and by more than fifty social services and organizations. In order to guarantee quality and cost control, Loaves \& Fishes established a modern facility as a central kitchen. At each center or site, there is a paid manager who oversees the meal time preparations, and a steering committee to guide the center's operation and to develop local financial and volunteer resources. A group of trustees, with participant representatives from each center, and others from the community-at-large form the governing board for the overall program. As indicated previously, at least 50 social agencies are linked into the program's referral and information system. A small staff of professionals provide guidance for center managers, outreach, coordination of program development, nutrition planning, education, public information, and other functions.

While the Loaves \& Fishes program is partly funded by Title VII of the 0lder Americans Act, participants still contribute to the meal cost on a pay-as-you-can basis. Many senior citizens who are not "poor" are feeling the adverse effects of inflation, and even though a tough rein has been kept on the Loaves \& Fishes costs, donations in the forms of nickels or dimes do not being to cover the ever mounting expenses. Hence, the staff continues to brainstorm fund raising ideas in order to generate more financial resources. 
Over the years, a realm of support services has been established, which has literally turned each Loaves \& Fishes center into a minisenior center. Having made the general decision to be real participants, and not simply passive recipients, the program offers senior citizens transportation to and from the centers when necessary, and provides them with social, educational and creative outlets, as well as a nourishing meal.

The transportation activity has evolved. into an autonomous transportation coalition which takes seniors on planned outings and short trips, as well as the meal locations. The crafts programs at each site sometimes result in sales which augnent much needed funds for the centers. Entertainment, which often accompanies the meals, involves more community spirited people in the program. Health oriented activities include low cost flu shots and nutrition education. Having visited five of the 25 Loaves \& Fishes centers personally within the last three years, I spoke to 31 participants in the program. I think one 83 year old participant puts it best when asked her assessment of the program. She said, "It's a beautiful experience!"

4. Northwest Pilot Project--Northwest Portland has become one of the largest concentrations of older persons in the entire Multnomah County area during the mid-60's. Due to the fact that it is located near the central business district, there are large groups of alcoholics, transient workers, the lonely and the so-called "Skid Row" group. Some of these elderly persons continued to live in family residences, or in fairly elaborate hotels. But most of the elderly live on very limited incomes in older hotels or apartments, or in deteriorating single family dwellings. There are many poor, isolated, lonely, 
friendless who deserved close attention of an agency equipped to extend kindness, such as the Northwest Pilot Project.

On February 15, 1965, the Chaplain of Good Samaritan Hospital and Medical Center was asked by the Pastoral Care Commission of the greater Portland Council of Churches to begin a pilot program of pastoral care services to the older adults living in the northwest area of Port1and. The chairperson of the Commission wrote at that time, "We are overwhelmed with the magnitude of opportunities and need for some attention in this area, whether for direct pastoral service, or cooperation with other volunteer groups or some possibilities yet unknown" (Paulson 1977). The intent of the Northwest Pilot Project from its beginning was to develop a program slowly so that eventually a more permanent program of volunteer services, under professional supervision, could be established to help older adults maintain their personal well being in their residences, with the hope the project could serve as a model for similar programs.

On October 1, 1969, the Northwest Pilot Project was launched with a grant requiring matching funds under Title II of the 01 der Americans Act of 1965 .

The major emphasis of the Pilot Project is on comprehensive volunteer service of supportive care to the aged, blind, and disabled. Specifically, the present efforts and continued objectives of the program include such services as elderly group education, friendly visitation, telephone reassurance, escort service, and advocacy services. Their definition of advocacy is:

Service of supportive concern and care within a one-to-one relationship, where trust is kindled, confidence renewed, and friendship is born. The advocate in his or her relationship 
with an older adult finds a supportive relationship with one of the community aides in discovering community resources for the elderly. (Paulson 1977a)

During the 1977-78 fiscal year, it is estimated that the Northwest Pilot Project will provide escort services to 50 elderly persons per month in downtown Portland. These escort services involve the examination and needs of services as part of the ongoing planning process to develop recommendations to modify delivery of services as appropriate, and in accordance with the Area Agency on Aging plan of services. Northwest Pilot Project is also providing at least friendly visitation to a minimum of 50 elderly persons per month, as well as telephone reassurance to 67 elderly persons; al so recreation to a monthly average of 64 older persons, and elderly group education to an average of 34 seniors. It is also estimated that the project provides responses to approximately 1536 requests per month, which include referrals to an estinated 768 persons. The project also provides outreach services to at least 25 elderly citizens per month.

The project director enumerated the program's commitment to human services and its successes in this manner:

Staff and volunteers of the Northwest Pilot Project are ready to be supportive in any way officials and planners for aging services so designate. Our primary concern is that individual citizens who are aged, blind and disabled, of low income within the community, not only be heard and heeded, but be given more encouragement and opportunity to accept responsibility and leadership towards community growth and development. (Paulson 1977b)

5. Foster Grandparent Program--Due to some uniqueness of the Foster Grandparent Program throughout the United States, I selected it as one of the six samples of elderly service projects that should be analyzed in terms of services provided to the elderly in Portland- 
Multnomah County. This projectwas established in 1965 immediately after the passage of the 01der Americans Act. In reviewing the guidelines of the Foster Grandparent Program, it was evident that it was designed to deal with social roles of the older persons in our society. For example, Elaine Brody discusses "The Etiquette of Filial Behavior" (1967) and sketches for us some of the reasons our current values in this rejard are outmoded; however, she is saying that our current roles make these relationships difficult to maintain. We have had a strong social expectation that the aged parents must be taken into the home of the adult child when he can no longer 1 ive alone; in many cases, strong disapproval is visited upon the family who "puts a grandparent in a nursing home." It seems what the family needs are additional supportive services to help it carry out its responsibilities, not accusations that it wants to abrogate the responsibilities.

It was the intent of the 01 der Americans Act to provide opportunities that would permit the elderly person to continue to provide constructive useful services on a volunteer or minor employment basis. Not very long ago, Edwin Newman wrote of his feelings as he became an "aging professional"; ir. Newman is a news commentator and critic who finds himself growing old, but is still active in his work. In some ways his article seems the beginning of a life "review," a thinking over of accomplishments of his $1 \mathrm{ife}$. Putting them in context, he realizes he is pleased and satisfied with himself. However, Newman sounds more or less pessimistic as he states, "I have to keep up. To which has to be added the discomfort of the beginning of the realization that keeping up is going to become 
harder, because the gap between youth and age is going to become wider" (Newman 1976). Although in Newman's profession there may be no compulsory retirement age, and al though he might not have problems with income maintenance, he presents a striking portrait of the man who realizes his occupational role will not be his own much longer, that his profession is changing to accommodate a new generation of whom he is not sure he totally approves. Hence, the Foster Grandparent Program in the Portland area has provided services that were greatly needed by several service organizations while permitting the older person to continue to perform usefut, constructive services to the clientele involved, namely, handicapped children.

The general purpose of the Foster Grandparent Program during the past 12 years of its operation in Multnomah County is to provide meaningful part-time volunteer opportunities for low income older persons, to render supportive person-to-person services to children with special or exceptional needs in health, education, welfare, and related conditions. As indicated above, the Foster Grandparent group focuses primarily on a person-to-person, continuing relationship. In order for an elderly person to qualify for the program, he or she must be 60 years of age or older, have a total annual income from all sources at or below $\$ 2866$ for an individual, and $\$ 3722$ for a family of two, and must be physically and mentally able to serve.

Here are a few of the major accomplishments of the project during the period 1976-1978.

Approximately 129 children at the Providence Child Center, Waverly Children's Home, and various churches received personalized services from about 37 adult 
"grandparents," in order to make positive advances in their social, emotional, and physical development. (Foster Grandparent Project 1978)

Plore specifically, they provide the following functions and services:

1. Arrange and provide four hours of monthly orientation in their respective centers, directed by specialized personnel to ensure optimum contribution and fulfillment for Foster Grandparents.

2. Ensure adequate preparation in providing personalized services to the children (feeding, playing, etc.).

3. Foster Grandparents have been meeting once each month with each service agency representative to coordinate and discuss operational difficulties.

4. Contribute to the socialization and health of the volunteers by providing one nutritious meal per day at volunteer services.

5. Assist the mobility of volunteers by arranging transportation between their homes and their assignment.

6. Contribute to the health and welfare of volunteers by providing physical examinations to ensure that they are physically able to serve without detriment to themselves, or to the children that are being served.

7. Enhance developments of at least 124 handicapped children whose developmental problems were sufficiently severe to exclude them from ordinary home, school and community experiences by providing the unique normalization services of 37 Foster Grandparents.

8. Focus volunteer activities on a one-to-one basis by personalizing grandparent to grandchild relationships.

In looking at the evaluation of the services provided by Foster Grandparents, and the services received by the clientele 
or recipients, it was extremely difficult to determine a financial cost on these services, since the benefits derived by both the recipients and the foster grandparents have been so extensive.

On the surface it would appear that a Foster Grandparent receives $\$ 1.60$ per hour stipend; however, the stipends were not treated as wages or compensation for the purposes of unemployment, temporary disability, retirement or public assistance. As a matter of fact, stipends do not in any way el iminate the level of eligibility for assistance or service any "Irandparent" may be receiving through state or local government programs. In talking to the staff persons, including the paid director, some foster grandparents, and some of the organizational stations, such as Providence Child Care and Waverly, it was apparent that the Foster Grandparent Program has had profound impact on the recipients of the services, as well as the grandparents themselves. One grandparent who is now 75 years old stated, "I can still get up and perform some useful services which continues to make my life more useful and constructive in our present society."

6. Gresham Senior Adult Center--During the fiscal year 1969-70, the Gresham Senior Adult Center was established primarily to provide recreational services to the elderly citizens in East fultnomah County. There were many indicators that the senior citizens in Gresham and/or the East Mul tnomah County area were interested in providing other services, however, as the needs arose. Hence, the center began to provide services to the socially isoalted person. It increased the knowledge of services and accessibility to community services by initiating a center newsletter. Through the center's efforts a large 
number of seniors' homes have been upgraded, housekeeper and home repair services have been provided, and some of the elderly persons have been relocated in better homes or apartments. The center also increased access to social, economic, and health services to at least 150 elderly residents who required supportive services to prevent institutionalization. This was accomplished by a field counselor, whose salary was subsidized by liultnomah County and Project ABLE. The director, Tim Boeshen, in an interview on March 13, 1978, indicated that the center has made a tremendous impact upon the elderly persons in the following areas.

1. The center was able to provide constructive, healthy, recreational services which relieved the loneliness; at the same time created or stimulated an environment which was conducive to good mental health.

2. With home repairs completed, the home environments changed from houses with leaky faucets, cold rooms, and poor lighting into a home of relaxation, a place which they are proud to call home, thus reducing the possibilities of premature institutionalization.

3. Counseling the senior citizens in terms of the best nutritional value that can be obtained during a skyrocketing inflationary system, enhances their health and prevents or lessens frequent hospitalization. Good nutrition al so lessens the susceptibility of becoming $i 11$ more frequently. Transportation provided the elderly made it possible for them to participate more frequently in recreational activities which included potlucks, quilting, numerous crafts and games at the center. The transportation made it possible for elderly to receive medical treatment at numerous medical centers. The 
center also participates in the Loaves \& Fishes program, whereby approximately 1500 meals are served on a weekly basis.

Perhaps one of the center's most outstanding annual events is the bazaar, which usually generates large sums of funds in order to supplement some of the senior citizens' activities.

One of the unique features about the Gresham Senior Center versus other centers, is the fact that many of the senior citizens have a sense of pride and ownership in the center itself. Many of the elderly persons in the Gresham Center are retired professionals and craftsmen such as carpenters, electricians, and plumbers who volunteer services to the elderly who are not physically or economically able to help themselves.

According to the present services agreement with the Area Agency on Aging, the Gresham Center is now providing escort services to at least 166 elderly persons in East Multnomah County; visiting at 1 east 166 persons in their homes; providing telephone reassurance to at least 220 elderly persons; and continuing to provide recreation on a monthly basis for at least 210 elderly persons. The center is also now providing "case management services" to at least 541 elderly persons in the east county area.

In analyzing the numerous services that have been provided by the Gresham Center in the past eight years, a remark by one of the ladies says it best, "I feel like I have a share in the center; yes, I indeed feel like I own it." 
SPECIFIC EFFECTS OF THE 1973 AMENDMENT OF THE

OLDER AMERICANS ACT

The 01 der Americans Comprehensive Services Amendments of 1973

included a declaration of objectives. Here are some accomplishments

that have occurred not only in the Portland area, but throughout the state of Oregon.

The Congress finds that millions of older citizens in this nation are suffering unnecessary harm from the lack of adequate services. It is, therefore, the purpose of this act, in support of the objectives of the 0ider Americans Act of 1965 to. .

1. Make available comprehensive programs which include a full range of health, education and social services to our older citizens who need them.

2. Give full and special consideration to older citizens with special needs in planning programs and, pending the availability of such programs for all older citizens, give priority to the elderly with the greatest economic and social need.

3. Provide comprehensive programs which will assure the coordinated delivery of a full range of essential services to our older citizens, and where applicable, al so furnish meaningful employment opportunities for many individuals, including older persons, young persons and volunteers from the community.

4. Insure the planning and operation of such programs will be undertaken as a partnership of older citizens, community agents and state and local governments with appropriate assistance from the federal government.

(01der Americans Act 1973)

Hence, the Administration on Aging had clearly prescribed steps for strengthening state agencies responsible for aging programs, the designation of planning and service areas, and establishment of area agencies on aging within the Portland-Multnomah areas, and several other counties throughout the state of Oregon.

In effect, the passage of the 01 der Americans Comprehensive 
Services Amendment of 1973 provided inpetus for local government to plan and implement the Area Agency on Aging component within Multnomah County. Thus, during the 1973-74 fiscal year, the City-County Commission on Aging began to develop the first year plan for the AAA, which was later adopted and coordinated through the City of Portland, Human Resources Department. Specifically, the first year goal was to establish a central administration unit known as the Area Agency on Aging, to monitor and coordinate a comprehensive array of services to elderly residents, with emphasis on maintaining service levels and allowing for growth in an orderly and timely fashion, and to perform ongoing planning in coordination with other public and private agencies to meet more effectively the needs of senior citizens within Multnomah County.

Between April and July of 1974, the Area Agency on Aging was officially transferred into the City Bureau of Human Resources. Since there were several model-aged programs that were operational and had significant impact within the Portland-Multnomah area, such projects as Project ABLE, Senior Adult Service Center, Senior Adult Center of Gresham, etc., had demonstrated effectively that several agencies can work together on behalf of shared clients. Due to the tremendous impact that these programs made during the demonstration period, a functional structure was designed in order not to deliver services directly, but rather to coordinate the delivery of services by other agencies. In this capacity the Area Agency would have dealt with both resources and services. 
COMPREHENSIVE AGING PLAN SINCE THE EXISTENCE OF

THE AREA AGENCY ON AGING

In reviewing the major objectives of the Triple $A$ system since

1973, it is evident that the following reflects the most significant functions that were being planned and for the most part implemented

in Portland-Multnomah County.

A. The Area Agency on Aging was required to secure and maintain maximum independence and dignity in a home environment for the older persons capable of self-care with appropriate support services.

B. It was responsible to remove individual and social barriers to economic and personal independence for older persons including the provisions for opportunities for employment and volunteer activities in the communities where older persons live.

C. It was also the responsibility of AAA to provide for development and implementation by the area agency, in conjunction with other planners and service providers, and other consumer agencies, of an area plan which sets forth specific program objectives and priorities for meeting the needs of the elderly with special attention being given to the needs of the low income and minority older persons.

D. To increase the capability of the area agency to develop and implement action programs designed to achieve coordination of existing social service systems in order to make such systems more effective, efficient, and responsive in meeting the needs of the elderly.

E. Draw on existing resources from public and private agencies that can be utilized to serve older persons, and encourage such agencies to enter into cooperative arrangements directed toward maximum utilization of existing resources on behalf of older persons.

F. Make existing social services more accessible to older persons in need through the development and support of services such as transportation, outreach, information and referral, and escort which can increase the ability of older persons, including older physically and mentally disabled, to obtain other social services. 
G. To promote comprehensive services for the elderly through the development of social services which are needed by older persons but are not otherwise available. (01der Americans Act 1973) 
CHAPTER $V$

\section{SIGNIFICANT ACHIEVEMENTS OF THE OLDER AMERICANS \\ ACT IN THE PORTLAND-MULTNOPAH AREA}

In recognition of the myriad elderly needs, the 196501 der Americans Act was passed by the United States Congress with the intent of alleviating or resolving the major problems which confront the elderly population. Here is a review of the specific components addressed in determining the impact of the 196501 der Americans Act in the Portland-Multnomah area: (1) income; (2) employment and retirement; (3) transportation; (4) housing; (5) physical and mental needs; (6) nutrition; (7) roles and activities. In 1970-71, the Senior Adult Service Center, through the auspices of the City-County Commission on Aging, conducted a study which utilized 800 questionnaires in reference to the services that the potential recipients felt were needed. One of those questions specifically addressed the present income of the low-income elderly persons. Since I was personally involved in conducting the study, it was observed that the income for the elderly persons ranged from $\$ 85$ to $\$ 130$ for single persons and for elderly couples ranged from $\$ 112$ to $\$ 190$. The average income for single elderly was $\$ 105$ per month. During the same time period the State Program on Aging of the state of Oregon conducted a study which reflected that the major source of income for the elderly was from Social Security and/or old age social 
insurance with additional sources of income from employer pensions, businesses and investments, savings, employment and old aye assistance (State Program on Aging 1971).

\section{$\underline{\text { Income }}$}

In the study conducted by the Senior Adult Service Center, 98 percent of the senior citizens felt that the lack of adequate incone was the major cause of most of their problems. Herice, it was the consensus of the elderly that increased retirement income or benefits of major portions will solve many of their problems. Thus, the inadequacies of current provisions for the elderly have been sensed by many community leaders, legislators, and other politicians who are concerned about the welfare of the elderly. First bills were introduced in Congress which would remove the statutory limitations in earnings which so often acted as a deterrent to individuals accepting employment, for fear of reducing or losing their Social Security benefits.

The late Robert F. Kennedy proposed at least 50 percent increase in Social Security benefits so as to meet the actual financial needs of the elderly. The National Council on Aging has reminded us that income derived from Social Security benefits falls below the official definition of poverty, and that according to the definition, "some 5-10 million live in poverty, and the latest increases granted in 1971 by the House fixed the benefits still below the poverty level (National Council on Aying 1967). Feeling that the elderly "have 
a right to share in the prosperity they help to create," the Council contends that Social Security benefits should be considered not only in relation to the cost of living but to the standards of living (Sprague 1967). Even the increases granted in 1971 failed to achieve this objective. Seventy-five percent of 117 elderly persons were interviewed five years later after the study was conducted by the Senior Adult Service Center in 1975, it was determined that the lowest income was a $\$ 160$ for a single adult and the highest was $\$ 189$. It was determined for couples the range was $\$ 225-305$. It was also pointed out by 95 percent of the senior citizens interviewed that al though their income had increased, with the rapid increase in inflation, they are still unable to meet some of their basic needs such as utility costs, heating, medication.

The importance of the el ement for adequate income for the aged has been continually impressed on us by the fact that during the 1968, 1972, and, most recently, 1976 presidential elections, the nominees endorsed the need for automatic increases in Social security benefits to keep pace with the cost of living, and for reduction and eventually elimination of the current restrictions on earnings.

Some of these changes have been put into effect on a piecemeal basis. Despite this augury for the future, there persists a significant lag between the actual needs of the elderly and acceptance of the obligation to meet these needs in Multnomah County. This apparently is the case on a national level. According to testimony by Bernard E. Nash (1971), Executive Director of the National Retired Teachers' 
Association, American Association of Retired Persons, on Health, Education and Wel fare appropriation bill,

While the 1971 fiscal year budget request for the Administration on Aging was 32 million dollars or $\$ 3,640,000$ more than the 1970 appropriation, it falls far short of the $\$ 54,650,000$ authorized by the Congress. This attitude of the Administration has ignored the intent of Congress, frustrated the desire and needs of older Americans and failed to recognize the social and economic impact on the country of increasing numbers of older persons (Nash 1971).

Much more remains to be done to effect an improvement in the financial situation of the elderly in Multnomah County and throughout the nation. The elderly are more and more aware that Social Security benefits, even when combined with private pensions such as railroad retirement, is inadequate. These are too frequently not sufficient to meet the ever-escalating cost of living.

Perhaps the most hopeful sign is that groups of elderly are beginning to voice their disillusionment over the failure of the affluent society to manifest a greater concern for their needs. They are beginning to develop a pride and solidarity as a group and have demonstrated their ability for organized action. This was evidenced when the Oregonian, on September 26, 1976, carried an article entitled, "Senior Citizens Prepare for Assault on the 1977 Legislature." The fact was that the Administrator of the Governor's Task Force on Aging testified that 21 percent of the Oregon senior citizens between age 60 and age 65 are living on incomes below the poverty level defined by the federal government,

...that level is $\$ 2,800$ per year for a single person and $\$ 3,700$ for couples. Move the index to those 65 
and 01 der and the poverty margin goes to more that $25 \%$ of the votes as compared with $51 \%$ costed by those $27-24$ years of age.

While income for the elderly has increased substantially since passage of the 196501 der Americans Act, all eridence reveals that 75-80 percent of the elderly population in Multnomah is tremendously short of adequate income after their retirement. Recognition of these deficiencies lead to periodic legislation to liberalize the payments. Even with the increased benefits of Social Security, however, income fails to keep pace with rising costs, either in absolute or relative terms and thus fails to assure the security that the Act was intended to provide. In many instances, the amount of benefits falls below the minimum budgetary requirements set by the U.S. Department of Health, Education and Welfare. There are still many persons over 60-65 who are disheartened because they are unable to meet their needs with limited income and resources at their disposal.

\section{Employment and Retirement}

The most depressing fact influencing the economic status of the elderly group is the practice of mandatory retirement at a fixed age. This practice, of course, came into being with the passage of the Social Security Act, which legislated 65 as the age when one should be considered old, with the implication that his or her productive years are over. The mandatory age of retirement was raised to age 70 in 1978.

There are many secondary reasons used to justify the practice of retiring older workers while they are able to continue to work. 
Such reasons are the need for younger workers to perform timely employment opportunities, the need for "new blood" in commerce and industry, and the progressive slowness of the older person to adjust to changing requirements. These reasons may or may not apply in individual cases. At best, they are only rationalizations and excuses. Meanwhile, the logical removal of the older worker from the labor force is proceeding rapidly. The statistics indicate that the number of persons over 65 in the labor force decreased from three-fourths of the total in 1900 to one-sixth in 1970.

What is frequently lost sight of is that strict adherence to such practices may be shortsighted on the part of the employer, as well as detrimental to the economy in general. The employee is deprived of knowledge and skill of an experienced worker while spending money in training a younger person. At the same time, the retired worker subsists, in many instances, on an inadequate income. As a result, he or she not only fails to produce goods, but is compelled to consume less.

Prior to the year 1965, there was no employment program that included senior citizens in Multnomah County in general. While many senior citizens work in private homes, babysitting and performing other domestic chores, their employment was nonexistent in public or private sectors in general. Since the passage of the 01 der Americans Act in 1965, my findings reveal the major employers of senior citizens in Multnomah County are public governmental agencies or non-profit organizations such as the Metropolitan Family Services. 
Here are the findings:

1. These agencies included the Foster Grandparent Program, which employs 33-43 part-time elderly citizens with a stipend ranging from $\$ 1.25-\$ 1.60$ an hour. This program is funded by ACTION.

2. Senior Adult Service Center Program, which developed a unique concept of "employing senior citizens to assist those senior citizens who cannot help themselves," employed 30-44 senior citizens from 1371 to 1975. The Model Cities Center was funded by the Housing and Urban Development Commission during that period.

3. The City-County Commission on Aging, whose employment prograni was funded by the Department of Labor, employed an average of 53 older persons on a part-time basis from 1970 to 1974.

4. Metropolitan Family Services al so employed a large group of outreach workers who are senior citizens to perform personal chores within other senior citizens' homes, average number of elderly employees was approximately 27-40 persons from 1975 to 1977.

The last agency I reviewed in analyzing the employment of senior citizens in Portland-Pultnomah County is the City Department of Human Resources, which is pres'entiy implementing the Area Agency on Aging program. They employ senior citizens under the Comprehensive Employment and Training Act (CETA).

In talking with some administrators and employees of the agencies previously mentioned, it was revealed that most of the senior citizens who were working did not in any way fit the stereotype of elderly employees. They were neither absent more often nor underproductive 
nor incompetent. The study reveals that most elderly are prompt, dependable, and usually go beyond the call of duty to complete assignments. For example, an 83 year old person employed by the Senior Adult Service Center refused to take a vacation during the two years of her employment at the agency. With a stipend of $\$ 2$ per hour for four hours a day, five days a week, most of these senior citizens are able to supplement their meager retirement incomes, which ranged from $\$ 85$ to $\$ 130$ per month.

Since the advent of the CETA program in 1975-76, there has been proven vast discrimination against those persons who are older and retired. A report completed by the U.S. Commission on Civil Rights in December 1977 revealed vast differences between employment of the older and the younger. Specifically, the elderly were given many excuses why they were not employed. The problem of employment has been particularly severe in terms of the elderly minorities who were interviewed in the Albina area. This is consistent with the report which was completed by the Civil Rights Commission. Congressperson Mario Biaggi identified the issue in the following manner:

If these elderly persons are members of an ethnic or racial minority and have suffered discrimination all of their lives, must they now meet up with a new form of discrimination for their remaining years?

The problems of older persons who are members of minority groups have been recognized by some mental health professionals. The Group for the Advancement of Psychiatry reported in a 1971 study: 
Being black and aged frequently means the piling up of life problems associated with each characteristic. The black aged often have less education, less income, less adequate medical services and fewer family supports than the aged in general; their vulnerability is often heightened by living in areas with a risk of assault, and robbery is high. Racism and agism may be combined to prevent the black aged from getting needed services of all types.

This finding was consistent in the study conducted in the Albina area which was approximately 40 percent of the elderly interviewed during this study.

In talking to several senior citizens who were desirous of working and could not obtain jobs because of their age, or those who were working but were in fear of losing theirjobs because of the statistical game which is presently being used by the CETA program, it is important to keep in mind that the problems of poverty and the stresses and strains of retirement have by-products which influenced more than the older person's reaction to their inadequate income, which quite frequently hinged upon their employment status or retirement benefits.

Since the inception of the CETA in Portland-Multnomah area, many senior citizens that were interviewed indicated that they were only allowed to work for a maximum of one year, after which time they would be laid off in order to permit younger and other persons to be employed in order that the program achieve "their federal quota for funding." In participating in some of the interviews, it was my observation that many of the elderly candidates were rejected or denied employment for the same reasons as specified by the Civil Rights Commission report. In many instances, employment opportunities 
were limited to certain age groups, in violation of the Age Discrimination in Employment Act of 1967. Illegal discrimination should never be used as a justification for denying opportunities to participate in federally supported services and benefits. Also it was revealed by the Civil Rights Commission report that "participation of persons in a certain age group in a program for all age groups should be restricted if an age categorical program exist to serve persons of that age" (1977). Age categorical programs are authorized to meet additional and special needs of people of certain ages. If a program intended for all age groups ignores the need of groups being served by programs, the age categorical program cannot achieve its purpose if the general program fails to meet its general responsibilities. Also,

$[A] d m i n i s t r a t o r s$ when confronted with limited resources should be permitted, in the interest of the most effective use of resources, to restrict services to specific age groups to the exclusion or limited participation of age groups. (Civil Rights Commission 1977)

The fact is that Congress may define eligibility for program participation in terms of age. If it does not do so, all who can benefit from the authorized services or benefits should be given the opportunity to do so. Administrators should not be permitted to rule out members of particular age groups as a matter of administrative expedience.

Hence, the study reveals not only discriminatory practices in the hiring of the elderly who are able to work, but also prevents the aged as a general rule from earning additional income that would supplement their small inadequate income. It was noted in the April 24, 1978 Oregonian that during a tour in Seattle, Dr. Arthur Flemming, 
former Secretary of Health, Education and Welfare said,

We found that despite the law which said we shall not discriminate on the basis of age, they were doing it all the time.... We have not done [a follow-up.] study on the basis of race.

In referring to the civil rights of the elderly persons, he stated that routinely the elderly civil rights were violated by the federal government's Comprehensive Employment and Training Program (CETA), as he noted in his capacity as Chairperson of the U.S. Commission on Civil Rights.

Here is a program that deals with billions of dollars, and we ought to be in there with some kind of follow-up. In addition to other things we ought to find out how they determine if there has been discrimination on the basis of age. I am very much inpressed with what CETA could do, but not so much with what they have done. (Oregonian April 24, 1978)

In sunmary, while there are riany employment opportunities for the elderly and while some elderly persons have benefitted by those opportunities, the fact remains that those elderly persons who receive jobs for over a year are still in the minority.

\section{Transportation}

An increase in transportation services in both urban and rural communities was seen as one of the priorities laid out by the 1960 White House Conference on Aging. The transportation problems of the elderly had become more urgent by 1970-1971. For example, an inventory of transportation services for the elderly in Portland-Multnomah area revealed that those services were provided primarily by the Senior Adult Service Center from 
1971 to 1975 with a monthly ridership of 1,300 . This study revealed that the Loaves \& Fishes program provides a certain limited number of rides to the elderly who participate in that program; the Portland Housing Authority also provided occasional transportation services for those elderly persons occupying some of the Housing Authority facilities; at one time or the other, a "project mobility" was established as a non-profit agency and was contracted by the City of Portland to provide a certain number of rides. Tri-Met was also contracted by the City to provide some ridership to elderly and handicapped persons. While some volunteer organizations and public agencies such as the State of Oregon Department of Human Resources (Adult and Family Services) provide some ridership exclusively to their particular clients, there has been a minimum progress made in this particular component.

While there has been a transportation referral system established through the network of eight Area Agencies on Aging, testimonies received by clients, potential clients, and employees of the Senior Centers as well as administrators, reflect that the present transportation for elderly is undependable, ineffective in terms of timeliness in meeting their appointments with clients, and in general does not provide for a prompt and dependable service for the elderly. The paradox is that most of the elderly cannot afford to pay transportation costs. For those senior citizens who are receiving public assistance (welfare), Adult and Family Services does provide transportation when there 
is no alternative resource; hence there are 1 iterally hundreds of senior citizens who are still falling between "the cracks" of social services. From all the demonstration projects and services that were analyzed, the most effective program was accomplished by the Senior Adult Service Center prior to the elimination of that transportation component in 1975. In observing the performance of the Senior Adult Service Center project, two radio equipped, 12-passenger buses were able to provide prompt services; with a day or two notice and occasionally without notice. Myriad services were provided. Such services prevented the exposure of senior citizens to mugging and assault and battery by providing portal-to-portal services to medical institutions and shopping centers. This kind of system is the epitome of what transportation services ought to be.

Housing

As indicated in Chapter II, the Portland Housing Authority completed an extensive housing study for the elderly in 1959. The results of this study disclosed dilapidated housing for the elderly as well as a tremendous lack of housing for the aged in the Portland-Multnomah area. The result of this study also indicated that there were approximately 500 housing stock in 1959 . Seventy percent of those were inadequate in terms of safety, basic utility requirements, appropriate electrical wiring. These shortages and conditions of housing in Portland-Multnomah County in 1959 and 1960 reflected a typical condition throughout 
the United States. According to the U.S. Senate Special Comittee on Aging (1971), the housing needs of the elderly were summarized this way: There is not enough housing for the aged; much of what is available is unfit for habitation; older Americans suffer from a lack of housing ability.

Housing adequacy is indisputably associated with income. In the Project FIND survey (1978) on the quality of housing, 31 percent of the aged poor respondents rated their housing as fair or poor. According to the survey findings from elderly poor respondents, almost half had no central heating and about one-fifth had no toilet, bathtub or shower, hot water, nor telephone in their houses and 15 percent had neither radio nor television. Twelve percent had no running water.

Since one of the riajor elements of Title III of the 01 der Americans Act required an increase in adequate housing for the elderly, there has been several buildings constructed in the PortlandMul tnomah County area that are now providing public housing for the elderly. For example, in May 1978, the Housing Authority stated that 1,800 units were presently occupied, and there were approximately 2,100 elderly persons on the waiting list (Portland Housing Authority 1978). 
While the emphasis on some of these objectives was not all successful, they epitomize the kinds of objectives that were actually implemented since the establishment of the Area Agency on Aging.

Of 97,000 elderly persons living in Multnomah County, through an evaluation analysis of the available statistical data since 1970 , it is estimated that an average of 26,000 elderly are being served annualiy in Multnomah County as a direct result of the 01 der Americans Act. (City of Portland 1977)

While the shortage of money limits the elderly to the types of housing they can obtain, the older persons also suffer further competition for housing. Physical impairment or general declining vigor interferes with their ability to shop around for an advantageous change. Often housing designs are still incompatible with their physical needs--high shelves, round doorknobs, inadequate lighting. Other considerations are the need to readjust living space as family members leave or die, and assistance with household personal and health services. Of the 71 elderly persons who are presently living in public housing, 67 percent indicate they were very satisfied living in public housing due to the low cost, the feeling of security, and the neighborly atmosphere that exists in the highrise apartments. Thirty percent expressed regret for leaving their own homes due to the fact that it is their opinion that they do not have the same independence, they cannot enjoy the personal surroundings of a garden, and the feeling of not having adequate 
privacy. Three percent expressed no feelings or opinions either way.

In this study, I also discussed with 46 senior citizens who are still living in their own homes if they are interested in living in apartments or public housing. An overwhelming 96 percent stated emphatically that they intent to live independently in the comfort and dignity of "our own homes," thus, avoiding what most of them have considered to be the need for early institutionalization in many instances. The other 40 percent indicated if the need arises they would be willing and happy to seek out the best housing available.

The units specifically designed for the elderly were built primarily with subsidies available under two sections of the National Housing Act: (A) Section 231 is a mortgage insurance progran providing non-profit sponsors with 100 percent insurance coverage and limited dividend sponsor 90 percent coverage. (B) Section 202 is the popular program of direct loans from the federal government to non-profit sponsors of housing, such as the Portland Housing Authority for the elderly and handicapped. Up to 100 percent capital cost is loaned to the sponsor who repays the government over 50 years at three percent. It has been one of the most effective and efficient federal programs; for instance, in 1968 the administration called for the replacement of this program. At that time 728 non-profit sponsors had submitted applications to build housing for the elderly under Section 202. No appropriations were requested for the program in 1969-70 and the accumulated backlog of Section 202 proposals were transferred for funding under Section 236.

Safe and adequate housing is the critical ingredient in an older person's environment. But it is not the only one. As resident 
populations of public housing and housing for the elderly grow older that cormunity's capacity to care for itself is altered. For example, I was recently informed by the Housing Authority that another 80-100 units are in the process of construction on North Williams Avenue and Russell Street. Many residents live alone and have no family nearby. Heighbors share the same needs--assistance in shopping and cooking, companions and nursing or personal care. Tholisands of aged persons living alone are able to care for themselves in Multnomah County and have been described as existing as if they were in a hospital or nursing home but without medical or social services typically supplied. Concentrations of need require assistance. In recognition of this situation, an important step was taken in the 1970 Housing Act which broadens public housing coverage including central dining facilities for older residents. For example, the Dahke Manor which is located at N.E. 9th Avenue and Schuyler; the 300 units which are located at 44 N.E. Broadway; Shrunk Tower at St. Johns; N.W. Tower at N.W. 20th Avenue and Everett Street are a few of the Portland Housing Authority projects which do provide dining facilities for the aged. The Loaves \& Fishes program operates out of most of those. The potential to continue to provide meals, increase socialization, and provide access to other services is promising. Group housing also applies to Section 236.

*For a more elaborate study of housing for the elderly before 1970, see The Elderly Oregonian Today State Program on Aging, December 1971 , pp. 50-53. 
While rental housing of different types for various income groups has grown, it represents only a start compared with the need in Multnomah County. Waiting lists are long and many do not apply since vacancies are rare according to many elderly persons. Majority of the elderly who need safe housing within their paying ability have little chance of getting it unless production is vastly increased in the next decade. Housing complexities with community centers, therefore, should be seen as a neighborhood resource for socializing, and services as a partial alleviation to live in substandard or inadequate housing for those who wait.

One of the major thrusts of the 1973 amendment to the 01 der Americans Act was to assure implementation of continued physical and mental assistance to the elderly. No longer were demonstration projects to be abandoned. Projects which modeled certain types of home help services proved to be successful in maintaining good or effective physical and mental health needs.

In reviewing the services available prior to the $196501 \mathrm{der}$ Americans Act in Multnomah County, such services as handyman, personal care, and counseling were practically non-existent or they were very limited. Those services that were provided were either completed by relatives or friends, or the elderly persons had to be institutionalized in a mental institution and/or hospitalized. Thus, since the inception of the 01 der Americans Act, the following services are being provided on a consistent basis to approximately the following number of senior citizens: (A) approximately 13,392 hours of homemaker services were provided to 160 elderly persons within the Multnomah County area during the fiscal years 1976-78; (B) escort services 
were provided to approximately 800 elderly persons to insure a safe and completed journey to various community services; (C) protective services are provided to approximately 157 elderly persons in order to prevent exploitation; in addition emergency housing was provided to approximately 90 elderly persons identified as disoriented or wandering by police officers; (D) friendly visitations were being provided to approximately 800 elderly persons; (E) telephone reassurance services were provided to approximately 1,055 elderly persons; (F) recreation services were provided to an estimated 3,030 elderly persons with an average monthly attendance of 1,$000 ;(G)$ elderly group education was provided to approximately 1,600 elderly persons with an average monthly participation of 533 persons and a minimum of twelve monthly leisurely and recreational activities in each of the nutritional sites (Portland Area Agency on Aging 1976). In talking to some of the outreach workers they are unable to provide some of the services due to the limited time from which they are permitted to do so. Specifically there was not an adequate number of workers to fulfill the proposed objectives. However, these services were provided and did make a major difference in the lives of at least five to six thousand elderly persons in Multnomah County. While the services are still scratching the surface of the need, it is moving into a positive direction.

Perhaps the most shortcomings can be identified in mental health services. It is apparent that this is not only a local problem, but national as well. Although older people represent about $10 \%$ of the population, they account for about 25 percent of mental hospital admissions. Once admitted, younger people are more likely to be 
treated and released. 01 der people, for whom psychiatric treatment is less available, are more likely to be committed than younger people. of the beds in the state mental hospitals, 40 percent are occupied by older people (Haddad 1969).

\section{Alternatives to Commitment}

Although some older patients are longtime residents and grow old in hospitals, in fact, state mental hospitals have been used as warehouses when other appropriate facilities are not provided. The policy of using state mental hospitals in this way is being changed. During the last decade there has been a great deal of discussion about "alternative courses of treatment," especially when there is a limited severity of symptoms present.

A study of civil commitment conducted in Washington, D.C., in a large federal mental hospital concluded that a large percent of persons committed to the hospital were older persons. In the following cases through the commitment process, research has found that in hearings with older persons social reasons overshadowed mental health reasons for commitment (Haddad 1969).

The law in that jurisdiction calls for a person to be mentally $i 11$ and a danger to himself or to others to be committed. It is often revealed in a hearing on an older person that he or she lives alone, on a fixed income, without relatives in the near vicinity. Although not senile, the older person may forget the gas is on after cooking or may have difficulties going up and down stairs. The danger of falling and not being able to call for help is ever present. Although not mentally $i 11$ in the sense of having a full-blown psychosis, and al though not dangerous in the sense of suicidal or homicidal, the constellation of social factors in the person's life constitutes 
a potentially dangerous situation for him. Hence, these elderly persons are frequently committed.

Having worked with an organization for the elderly for several years, and presently working for a state agency, the typical case described above has alternatives to hospitalization such as a nursing home, a visiting homemaker, a foster or group home. The question raised is who has responsibility for identifying alternative care-the family? the attorney? the hospital? the courts? (Hal1 1968) In talking to an unidentified source in Multnomah Mental Health Department, all the above alternatives are not necessarily exhausted because elderly persons may not always be "cooperative." At that point, however, the elderly person has already changed status. He or she has become a committed mental patient and the situation has changed in many ways. In talking and observing several thousand senior citizens for the past ten years in Multnomah County, it is my opinion that 55 percent of the elderly could resolve what has been described as mental illness simply with appropriate counseling and the provision of adequate services such as medical care, housing, socialization, and visitation by homemakers and outreach workers.

The availability of services to provide aiternatives to commitment is not the only issue. The other is the responsibility to develop these services. It is not sufficient to state simply that there are no alternatives in the community. With the few mental centers which are being operated by Multnomah County, many of the senior citizens are unable to obtain pre-counseling that would prevent them from going to these centers. The second step would avoid a need for commitment into the institution after careful screening by 
the medical centers. The need for nore programs and facilities must be documented, a case must be successfully made, and new services developed (U.S. Senate 1971). While Multnomah County has established an agency to serve as a guardian or conservator, the procedures must be clearly defined and be communicated to the aging population in order that it can be used at their discretion and option. As the population of older people increases, those with special needs will continue to increase. Therefore, the Multnomah community will need to look closely at their protective service system in order to improve the inadequate services in this area.

\section{Nutrition}

In 1965, the YWCA initiated, on a minor basis, a meals-on-wheels project. However, it did not even scratch the surface in providing adequate nutritious services to the large elderly population in Multnomah County. Hence, when the Loaves \& Fishes program started the implementation of nutrition services to the elderly, it was providing one of the most essential needs for the elderly.

In the past, the aged's concern was usually to get enough food. Dúring this century, the science of nutrition has developed and demonstrated that certain foods are better for us than others-that all of us need a balanced diet.

Hence, it is not surprising that many older persons know very little about proper nutrition. Those who are aware of proper nutrition are quite frequently so lonely, poor, and/or enfeebled as to be unable or unwilling to obtain properly nutritious meals on a daily basis. Many of them did not learn about foods in school 
nor in their childhood homes.

Of course there are many other reasons why older people may be lacking in essential nutrients. As indicated before, Project FIND found a large percentage of the elderly in Multnomah County were not receiving meals on a consistent daily basis because of lack of income or ignorance of proper resources plus being unable to pay for meals. Again, many older people are simply too poor to purchase the foods they need, and the actual purchase may be a problem because they lack convenient access to the stores on frequent occasions.

Many senior citizens are without teeth or wear ill-fitting dentures which makes chewing foods difficult. Others suffer from diseases that require special diets and create nutritional problems. Thousands of older people live by themselves, isolated from friends or relatives, with little incentive to cook proper foods. Loneliness, anxiety, and other emotions can affect the amount and kinds of foods people eat. Many studies have been demonstrated convincingly that acute brain syndrome, usually called senility, is often the result of malnutrition.

Therefore, when Loaves \& Fishes, Inc. served its first meal on February 9, 1970 at Lincoln Street Methodist Church in Southeast Portland, it launched what I have determined to be one of the most effective and efficient senior citizen services in the PortlandMul tnomah vicinity.

This program has been able to develop over 3,000 volunteers throughout at least 260 churches in the Portland area, and other neighboring counties, while providing several thousands of meals on a five-day a week basis to the senior citizens who may pay "as 
you can" for a daily nutritious meal.

This program has made tremendous impact upon the social lives of the elderly by the various recreational and educational endeavors being conducted daily from at least fifteen major sites. The total impact upon the health, social, and physical uplifting of the senior through the Loaves \& Fishes program is immense. All senior citizens who were interviewed are not only knowledgeable of Loaves \& Fishes but have expressed profound appreciation for the impact that this program has riade upon the lives of senior citizens throughout Multnomah County. While this program is being funded through Title VII funds through the Oregon State Program on Aging up to 1977 in order to supplement meals, it has proven very cost effective due to the massive volunteer efforts throughout the city and county to assist in serving the meals at these sites, as well as delivering over 500 meals to shut-in senior citizens. Perhaps an elderly lady said it best, when she stated; "I don't know how I'd get along without Loaves \& Fishes."

\section{Roles and Activities for the Aged}

It should be the concern of government, industry, labor, voluntary, and religious organizations that the elderly have gratifying roles and activities in our society. The family, as well as involved citizens, should also make concerted efforts to assure that senior citizens have the opportunity to participate constructively on the basis of their skills. For instance, an elderly person who may be fortunate and chooses to live alone would have a family or close friend nearby to depend on when help may be needed. The retired person would also have prepared himself for retirement by developing 
an absorbing interest during his or her lifetime. As a matter of fact, a few months ago one famous gerontologist advocated that an individual would be falling short of good planning if he or she did not begin to plan for retirement by the age of 30 . Frankly, a retired employee would also have options of traveling if he or she had the money, volunteering services in interesting causes, pursuing education, taking up a craft or art, and participating in civic and political affairs in the community.

Such is an ideal lifestyle for an elderly person. However, this has not been the case in Portland with the exception of a small minority of elderly who are wealthy and able to obtain those enjoyments as described above. In the real world too many older people do not have income that would provide such choices. While there are some existing recreational and educational opportunities suited to the needs of a small percentage of the elderly, they do not represent the total answer for meeting all the needs and requirements of the elderly persons. Many of the aged are overcome by feelings of frustration and uselessness as they find themselves removed from their previous careers and other worldly activities. Many of the elderly were raised in a culture which emphasized the importance of productivity, and once they are compelled to forfeit those previous activities, they miss the satisfaction which they derived only from productivity of their own choice and the status which such activity confers. Of course, this applies with particular force to those aged persons who are vigorous in mind and body, and who found that they have been deprived of such satisfaction by an arbitrarily determined age of 65 years. 
The significance or importance and appreciation of employing the energy and interest of the elderly in a few programs have led within the past decade to the development of a number of projects such as the Foster Grandparent program, Senior Adult Service Center, Northwest Pilot Project, etc. Those undertakings have demonstrated their value both in combating the feelings of uselessness, and in contributing to the welfare of the community. They have demonstrated that the elderly are capable of useful participation in worthwhile endeavors, can attain a sense of independence which they temporarily lost, and earn the recognition of others in the community. Many of these persons have testified to this fact. Ruth Haefner, who is 85 years 0ld, and co-chairperson of the Portland Gray Panthers Chapter, has eloquently discussed the issues of aging in 211 aspects and has made recommendations which could have profound effect upon the present and future aging population. Marie Smith, who is now 82 years old, and a member of the City-County Commission on Aging, in addition to being Chairperson of the Senior Adult Service Center Advisory Board, not only is instrumental in providing leadership in the elderly programs, but has demonstrated outstanding leadership in other community affairs--be it politics, economics, social or civic affairs.

Due to the importance which such endeavors have in helping to utilize the potentials inherent in the elderly and reclaiming them from the futility and depression to which they often succumb, it may be helpful to reiterate some of them in greater detail. For instance, the Foster Grandparent program nationally in 1966 employed approximately 4,000 older men and women who care for a 
number of children in need of attention, love, and help. In Portland this can be observed at the Providence Child Care institution on N.E. 42nd Avenue. The efforts of the foster grandparents proved so successful they have earned the enviable appellation "child savers."

In another instance in 1968 there appeared a report of a program using older people as mental health aides working in cooperation with schools to help children in lower grades who presented problems in the classroom such as underachievement, withdrawal or acting out. The older persons selected for that program varied in background and education. However, before proceeding to work individually with children, they were given a period of orientation and training. It was later found that these older persons were "receptive" to new learning and quite open in their approach to new ways of doing things. The myth of the elderly person who is unable to change is simply a stereotype held by some members of the younger generation. The results achieved were evaluated independently by retirees and schoolteachers, and there appeared to be considerable unanimity as to the success of the program, which was manifest in the improvement shown in the children's behavior as well as their better learning. On the basis of the report, the experiment demonstrated that retired people can be effectively utilized as non-professionals in a professional setting. The experience is an enjoyable and meaningful one for the participants who profit from it. The retirees' favorable reaction to the experiment can be considered a clue to the reason for the satisfaction they derive from it. The older people felt the experience gave them the opportunity to apply their wisdom and experience to 
a worthwhile task. The study concludes that "there is no reason to assume that schools are the only setting in which retired people can function effectively..." The findings suggest that retired people may constitute an important human service resource (Cowen 1968).

Prior to the formation of the Area Agency on Aging, the purpose of all the projects in Portland-Multnomah County was primarily to involve a large segment of the local elderly poor in the so-called war on poverty, as well as the demonstration projects described above. The elderiy people were employed to locate elderly people who needed service; arrange for information and referral; organize groups for self service; render a variety of personal services to the homebound and, in the process of doing so, involve others in rendering such services.

Through such participation, the elderly have been brought out of their isolation to a large extent. It pointed out that lack of economic self sufficiency, poor health, and other disabilities are 1 argely responsible for depriving older people of opportunities of life around them. Beginning with one-to-one relationships, there was a time in the projects--a spontaneous development of groups-in which the elderly themselves perceived areas of need which could be helped through group action. It was found that many of the elderly met the criteria for staff selection and can participate in the programs as teachers' aides, cooks, drivers, carpenters or handymen, arts and crafts, parents helpers, etc. Having talked to and interviewed 167 persons, 117 of whom were elderly recipients of services, I am convinced that the effectiveness of future aging programs will be determined 
by the degree to which the elderly persons participate. In talking with many directors of senior centers and agencies which are presently providing elderly services within the community, their enthusiasm in terms of what the future holds for the elderly in Portland-Multnomah County is somewhat reserved.

\section{CONCLUSIONS AND RECOMPENDATIONS}

In summary, if we were to ask what is the inpact of the 01 der Americans Act in Portland-llultnomah County, I would have to state emphatically, "Yes, there has been some impact upon the lives of elderly citizens." However, this should not be construed to mean the problems of the elderly are nearly solved. The following are some major accomplishments in Multnomah County since the passage of the 01 der Americans Act. With the exceptions of such national professional organizations as the American Association of Retired Persons, there was no exclusive service center or agency for the elderly in Multnomah County in 1960. However, I have taken an inventory in 1976-77 and noted at least 24 specific agencies providing some form of service to the elderly exclusively. I have also noted that there were no real commitments made by most local politicians up to the 1960 major election year; however, there has been significant changes in terms of the campaign promises made while numerous politicans ran for offices since 1968. Within the last two election years (1972 and 1976), I have read at least 31 brochures of candidates who were running for office and 29 of those brochures made specific promises that addressed the senior citizens' problems in Multnomah County. 
Since 1968, we have witnessed a budget allocation for senior citizens, planning and services have drastically increased from 30-60 thousand dollars to over a million dollars per fiscal year. In terms of the education of the elderly we have also noticed an Institute on Aging now becoming a part of Portland State University as one of the most urban schools in this immediate community. Prior to 1965, retired persons could only obtain babysitting jobs or perform domestic chores; this has changed drastically in that there are at least 10 to 15 public agencies and/or private non-profit enterprises that are employing up to approximately 221 senior citizens per year between 1970 and 1975. We have also noted that the problem of housing was addressed only on a minimum scale and it was not until the late ' 60 's that a major effort was made to build more housing for the elderly with special safety features or specifications. In terms of special transportation services for the elderly, we have observed some of the most effective transportation services during the period 1970 through 1975. These models have demonstrated that the senior citizens need for their own survival a form of transportation system that is safe in terms of portal-to-portal pickup and low cost in order that they may obtain not only medical services but also travel to the social and recreational services in our community.

While Multnomah County has provided some medical and mental health services to our senior citizens, it falls short of the medical needs of the senior citizens in our community. For example, the Public Welfare Division, now Adult and Family Services, has provided medical 
services to those senior citizens who are receiving assistance. However, for those senior citizens that are not receiving some form of public assistance, they fall between the cracks of the system.

Such social services as homemakers, telephone reassurers, information and referral, recreation, etc. have given hope to those elderly who were in despair prior to the passage of the $196501 d e r$ Americans Act.

While there has been incredible strides made in the field of nutrition for the elderly and other programs mentioned previously, I am reminded of the cliche which states "We have come a long way." It is my observation that we still have a long way to go in terms of providing effective, efficient, and adequate services to our elderly population.

The fact is that isolation, limited mobility, educational and the low income status which characterizes the older population, imposes more of a burden on minority elderly than on non-minority members of the community. Minority members have been historically deprived of the opportunities and benefits which should have been their's. For instance, administrators of programs are not taking sufficient steps to consider the multiple problems faced by many older persons and to increase their opportunity for obtaining needed services and benefits. An example of such situation is that age discrimination exists because some federal, state, and local program administrators develop policies which narrowly interpret statutory goals, the application of which limit the participation of certain age groups. For many 
program administrators, preventive health care under the comunity health centers programs means health care for children and adolescents. older persons are often considered too old to warrant an investment in preventive health care or viewed as unable to derive as much benefits as much younger people. At least four center directors and several federal regional office officials attributed this situation to the U.S. Public Health Service and Department of Health, Education and Welfare policies that associate achievement of the preventive health care goal almost entirely with services to children and youth. Preventive health care is a major theme of the recently formed forward plan for health for fiscal years 1978-82 prepared by the U.S. Health Service of the Department of Health, Education and Welfare (U.S. Department of Health, Education and Welfare 1976).

Dr. Julius Richmond, Assistant Secretary for the Department of Health, Education and Welfare explained in his written response to questions submitted by the Commission that, "It is expected that such preventive services will help to reduce the numbers and kinds of health problems that generations of aged persons will have" (1977). Assistant Secretary Richmond also noted, however, that the public health service is making efforts to expand its focus on health programs which he indicates would affect a significant portion of 01 der persons. He stated that recent active programs for screening detention diagnosis, prevention and referral for treatment of hypertension 
under Section $314(D)(7)(B)$ of the public service Health Act represents one step that his agency is taking.

This statement appears to overlook the importance that early detection and prevention of illness have for persons of any age. Today's older persons have much to gain from preventive care services. The "payoff" that results may equally be important to society, both economically and socially. Interpreting such a universally applicable phrase as "preventive health care" to apply primarily to a narrow age segment of the general population effectively diminishes the opportunities of other age groups to receive such care.

One of the most discouraging elements that seems to exist since $1975-76$ is the inability of many project directors to implement and utilize the state and federal guidelines as they would desire without undue alleged interference, or conflict by some of AAA staff members. For example, in the month of April 1978, about 250 senior citizens assembled at the Portland City Hall protesting possible cuts in the nutrition-transportation program. Many elderly committees and advisory boards are appealing to the Mayor for guidance and compassion in terms of utilizing the system to maximize the elderly resources to as many elderly as possible. These symiptoms seem to be creating some negative overtones that could set some of the outstanding accomplishments by various aging programs in Multnomah County back several years. Some of these probleris are due to a lack of understanding on the part of some administrators in positions of controlling allocation of dollars. The fact is, it is nearly impossible to administer and still operate programs effectively and efficiently. 
It is very encouraging to note some of the profound interest that at least $80 \%$ of the local politicians are demonstrating in favor of effective aging programs. All indications that I've observed in meetings, both at the centers' social gatherings, the City Council, etc. have shown that the elderly people as a group are becoming more politically alert and interest oriented than younger people. I would suggest that they have begun to approach that alertness and interest orientation of other groups.

It is apparent that the political needs of the elderly are now very great, as reflected, for example, in the reports of the Senate Sub-committee on problems of the aging and aged. However, this indicates the earlier political neglect of these needs, so that the prospect of much legislation for the benefit of the aged may be considered as accumulation of past political inactivity. As yet the demands of the elderly are still quite modest in terms of the needs. If these needs are satisfied without too much conflict, aging consciousness will reach a lower maximum than if the opposition to aging legislation provokes intense feelings and intense organization among the aging and their partisans.

Never before have we witnessed more political involvement on the local, state, and federal level. For example, we have seen such headlines as the one in the Oregonian on September 26, 1976, "Senior Citizens Prepare for Assault on 1977 Legislature." We have also noted on November 20, 1977, another Oregonian headline, "Oregon's 
Aged Comes of Age, Willing Political Clout." The Oregonian of March 31,1977 states, "New Breed of Elderly Requires Changes in Attitude and Social Patterns." These are a few of the major headlines that will force the politicians and the political structure to generate the necessary impetus that is required to obtain and implement effective elderly services within the community.

If the accomplishments which were completed in the last decade, that is from 1965 to 1975 are to be longlasting and improved upon, then it is imperative that the senior citizens continue to muster their political clout and experience against the various bureaucracies that exist in order to keep pace with a highly inflationary economy. The elderly need to combine the approach of the activist, as well as stress the training and preparation, research and background work of the other coalition elderly forces.

\section{MAJOR RECOMMENDATIONS}

1. A more comprehensive medical and mental health plan for the elderly be coordinated and implemented through the State Health Department rather than Multnomah County.

2. City-County Commission on Aging be given the authority to initiate any grievances that are submitted to the organization by a project or group of elderly persons. The Commission on Aging would act as an advocate whereby they would be given legal authority to evaluate the complaint and either resolve it in conjunction with the local service agency or proceed on a state or federal level to 
achieve a reasonable solution.

3. City-County Area Agency on Aging utilize the demonstration models that were most successful in providing services to the elderly. This includes the (a) portal-to-portal transportation system by Project ABLE, the Senior Adult Service Center; (b) continue to permit the Loaves \& Fishes program to operate the nutrition program that has been so successful for several years in the same manner which the organization implemented before the advent of the Area Agency on Aging. This would permit far more autonomy; hence, reducing the cost of meals to the senior, as well as maintaining a high level of volunteer participation within the community.

4. Employment for the elderly should be provided to those senior citizens who are alert, physically and mentally able and still maintain the skills that are required to perform the various tasks--handyman, information and referral, working with children through Foster Grandparents, working within the school system, etc. It should be further stipulated that no elderly should be terminated simply to play "the numbers game," meaning that if an elderly person is doing a good or excellent job, they would be able to continue to work indefinitely, rather than six months or one year.

5. The City-County continue to provide extensive social services to the aged population, such as described in Appendix $D$. This would provide for continuation of those effective services to the maximum number of elderly persons in keeping pace with the 
inflationary economy.

6. That the elderly poor be allowed to make as much income as they are physically able to earn, rather than the present $\$ 2,400$ per year; hence, their Social Security funds which they have earned through their younger years should not be limited due to the funds they are capable of earning.

7. That pharmaceutical conpanies provide discounts on medication for those elderly poor senior citizens, since medication is one of the highest costs to seniors.

8. That the Portland Housing Authority and other private investors be allowed to build housing that would accommodate not only the 2,100 elderly persons who are presentiy on a waiting list, but provide adequate housing for the estimated 1,000 elderly citizens potentially needing housing. This would accommodate the extensive costs that many elderly are paying for rent. It will also assure safe and secure accommodations for the aged in llultnomah County and the City of Portland. 


\section{PREFACE TO BIBLIOGRAPHY}

Having been a participant, as well as a continuous observer of aging programs in Multnomah County for nearly a decade, it has been often difficult to separate personal bias from objective reporting. This, I believe, will always be a difficulty for those who are involved in programs about which they write. However, there are substantial benefits to be derived from the writings of insiders.

It is only the insider who can indicate the first quiverings of a program's development. Generally, little or no documentation exists on programs until they are formalized in the system. Yet a participant will often be able to identify (through being present or knowing those who were) the meeting which started the system in motion. In addition, the insider will have dealt with the decision makers and will understand much of their motivations.

Both of these insights are needed if future historians and students of policy are to understand what took place and why.

There is, of course, the problem mentioned earlier of the author's bias. The insider, while having intimate knowledge and acute insight, often fails to document the argument. This problem is particularly acute when discussing the embryonic development of aging programs, where few documents exist and more than one program concept often competes for institutional and political acceptance. 
Throughout the writing of this thesis, I have kept these two problems in mind. Consequentry, I have attempted to use the insights and access gained as a participant, while at the same time reinforcing my analysis with data from the national, state, and local levels. As is often the case, the further down the tier one proceeds, the less structured and concise the data may appear.

The data relied upon at the local level pose special problems. Except for formal public documents, much reliance has been placed upon agency and interest group brochures, interviews with decision makers, and minutes of meetings. These data are difficult to replicate because minutes often get lost, emphasis or ideas given in an interview change with time, and old brochures are often thrown away. In addition, there is the problem that, until very recently, no one agency or group has been concerned primarily with the problems of the elderly. Consequently, the data gathered were diverse, sometimes sporadic, and inconsistent in coverage and emphasis.

Such data may be classified into three major categories:

1. Programmatic information, which gives a synopsis of aging programs that were funded by Housing and Urban Development (Model Cities), the Office of Economic Opportunity (Portland Metropolitan Steering Committee), and most recently, ACTION. All of these administrative agencies submitted an overview of all funded programs to the University Library for future reference.

2. Local non-profit aging projects maintained files that may or may not consist of historical data that were available 
during the period of this research. Typically, when a key staff person, such as a project director or supervisor, leaves an agency, there is a tendency to destroy or throw away information that would substantiate some of my findings in the analysis of certain phases of the projects. Hence, future researchers may very well find material in the files of such organizations as City-County Commission on Aging, Multnomah County Community Action, etc., which provide for a different perception due to the destruction of data I used in my study. I hope this overview of the various changes that I have observed from year to year on aging projects will alert students to the complexity and vast amount of information available while attempting to develop a central theme.

3. Personal Interviews. The perception of elderly needs, the supply of aging services, and the effectiveness of those services varied considerably through a common system of symbols. For example, some of those recipients interviewed who were primarily interested in receiving transportation services would identify housing for the elderly as a low priority; thus, they would emphasize the need for more transportation services versus an increase in housing for the elderly. On the other hand, those persons in desperate need of housing often held a directly opposite viewpoint. 
In summary, I frequently attempted to extrapolate substantive information based upon my experience with the subject, as well as my knowledge of the circumstances as they related to the individual's frame of reference.

Thus, this thesis is a synthesis, an identification of available information, as well as an analysis of the evolution of exclusive aging programs in Multnomah County. 


\section{BIBL IOGRAPHY}

Bornet, Vaughn D., 1960, Welfare in America, Norman, University of Oklahoma Press, pp. 236-237.

Brody, Elaine M. et al., 1967, The Etiquette of Filial Behavior: A Social Work Guide for Long-Term Care Facilities, National Institute of Mental Health, Rockville, Maryland, Washington, D.C., U.S. Government Printing Office.

Bryce, J., 1921, Modern Democracy, Vol. II, New York, liacmillan.

Cottrel1, W. Fred, 1960, Governmental Functions Politics of Aged, Handbook of Social Gerontology, Ed. Clark Tibbitts, Chicago, University of Chicago Press.

Cottre 11, W. Fred, 1971, Government and Non-Government Organization, Technical Paper for 1971 White House Conference on Aging, Administration on Aging, Washington, D.C., n.p.n.d.

Cowen, Emory L., 1968, "Utilization of Retired People as Mental Health Aides with Children," American Journal of Orthopsychiatry, Vol. 38.

Drake, Joseph T., 1958, The Aged in American Society, New York, Ronald Press.

Gilbert, Jeanne G., 1952; Understanding 01d Age, New York, Ronald Press.

Gold, Byron, 1973, "Issues Implicit in the 1973 Amendments to the older Americans Act," Perspectives on Aging, Vol. II, No. 5, National Council on the Aging.

Governor's Committee to Study Problems of the Aging, November 1954 , Report, Salem, Oregon.

Group for the Advancement of Psychiatry, 1971, The Aged and Community Mental Health: A Guide to Program Development, Vol. B, Report ilo. 81 .

Ha11, Gertrude, 1968, "Overcoming Barriers to Protective Services for the Aged," The National Council on Aging.

Harvey, LeBrun, 1936, "Evaluation of the American Pension System, 1883-1936," Sociology and Social Research XX, pp. 453-462. 
Havighurst, Robert J., 1952, "Social and Psychological Needs of Aging," pp. 15-16.

Hoddad, Patricia, June 1969, "Incarceration of Freedom: A Case Study of Civil Commitment of the Menta11y I11," Unpublished Thesis, University of Maryland School of Social Work Library, Baltimore, Maryland.

Holt et a1., 1971, Unemployment Inflation Dilemma: A Manpower Solution, The Urban Institute, Washington, D.C.

Holtzman, Abraham, 1954, "Analysis of 01d Age Politics in the United States," Journal of Gerontology, Vol. IX, pp. 56-66.

Huych, Margaret H., 1974, Growing 01der: Things You Heed to Know About Aging, Engl ewood Cliffs, New Jersey, Prentice-Hal1.

Loether, Herman J., 1975, Problems of Aging: Sociological and Social Psychological Perspectives, Encoina and Belmont, California, Dickerson Publishing Co.

Lubove, Ray, 1967, The Struggle for Social Security, 1900-1935, Cambridge, Massachusetts, Harvard University Press, pp. 135-136.

Nash, Sites, 1971, "Penny Pinching by HEW," Health, Education and Wel fare.

National Council on Aging, 1968, "An Invitation to Membership, Hew York.

National Council on Aging, 1973, Perspective on Aging, Vol. II, iNo. 5 .

National Council for Homemakers Services, 1964, Report, New York.

Newnan, Edwin H., 1976, A Civil Tongue, New York, Bobbs-Merril1 Co.

Oregon Governor's Committee on Aging, 1974, 01der Oregonians' Universe: Facts on 01der Oregonians, n.p.n.d.

Oregonian, Sentember 26, 1976, "Senior Citizens Prepare for Assault on 1977 Legislature."

Oregonian, March 30, 1977, "Senior Citizens."

Oregonian, March 31, 1977, "New Breed of Elderly Requires Changes in Attitude and Social Patterns."

Oregonian, November 20, 1977, "Oregon's Aged Come of Age, Wielding Political Clout." 
Oregonian, April 24, 1978, "Elderly Citizens."

Paulson, Peter, 1977, "Needed: Advocates for the Pursuit of Life, Liberty, and Happiness for 01der Americans," Northwest Pilot Project, Inc.

Phillips, Barbara A., May 1966, "Charitable Exemption for Homes for the Aging," A Brief of the American Association of Homes for the Aging, New York.

Pinner, Frank A., Paul Jacobs, and Philip Selznick, 1959, 01d Age and Social Behavior, Berkeley, University of California Press.

Portland Area Agency on Aging, Plan of Operation for 1976-77, Department of Human Resources, City of Portland, June 1976.

Portland Housing Authority, 1959, Status Report.

Saul, Shara, 1974, Aging: An Album of People Growing 01d, New York, John Wiley \& Sons, Inc.

Selznick, Philip, 1952, The Organizational Weapon, New York, McGrawHill.

Shanas, Ethe1, 1961, "Measuring the Home Health Heeds," Journal of Gerontology, New York Health Information Foundation.

Sprague, Norman, 1967, Testimony on the 1967 Amendments to the Social Security Act Before the Senate Committee on Finance.

State Program on Aging, December 1971, Elderly Oregonian Today, Salem, Oregon.

Sub-Committee on Aging, January 27, 1961, White House Conference on Aging Report.

U.S. Code, Congressional and Administrative News, Vo1. I, 89th Cong., 1st Sess., 1965, pp. 233-1885.

U.S. Department of Health, Education and Welfare, 1978, Public Health Service Forward Plan for Health.

U.S. Senate Special Committee on Aging, 1971, Developments in Aging: 1970.

U.S. Senate Special Committee on Aging, 1972, Memorandum. 
APPENDIX A

OREGON STATE COUNCIL FOR SENIOR CITIZENS

STATE OF OREGON

BYLAWS OF THE OREGON STATE COUNCIL FOR SENIOR CITIZENS

\section{ARTICLE I NAME}

Section 1. This organization shall be known as the Oregon State Council for Senior Citizens.

\section{ARTICLE II OBJECTIVES}

Section 1. The basic purposes of this Council shall be:
A. To identify the total needs of the state's senior population;
B. To inform and enlist the support and participation of all citizens about these needs;
C. To design, promote and implement services for seniors;
D. To be of assistance and cooperate with all agencies on the local, state and national level interested in providing services to the aging, or having purposes similar to this Council.

\section{ARTICLE III MEMBERSHIP}

Section 1. The membership of the Oregon State Council for Senior Citizens shali be composed of voting members and honorary members. Any person or group subscribing to the purposes and policies of the Council shall be eligible for membership and upon payment of dues shall become a member.

Section 2. Classes of membership:
A. Voting members
(1) Individuals
(2) Groups
B. Sustaining members 
C. Honorary members

Section 3. Dues

A. (1) The dues shall be one dollar per person per fiscal year.

(2) The annual dues shall be payable July lst, which is the beginning of the fiscal year. Any member who fails to pay his dues within four months of July lst shall lose their voting privileges.

New members paying their dues during the last quarter of the fiscal year (April, May and June) will be credited with full membership to the end of the following fiscal year.

B. The dues for groups with representation in the Council shall be five dollars per fiscal year for groups numbering fifty (50) or less and ten dollars per fiscal year for groups numbering fifty (50) or more.

C. Lifetime membership shall be twenty-five dollars.

Section 4. Persons who have paid individual dues shall be voting members and shall be entitled to one (1) vote and to hold office or to serve on the Board of Directors if so elected.

Section 5. A sustaining member would be an individual who contributes ten dollars or more to the Council annually.

Section 6. Any organization subscribing to the purposes and policies of this Council shall be entitled to a group membership, by paying the membership dues as stated in Article III, Section 3-B.

Such a group shall be authorized to send one (1) representative to all regular and special meetings and such representative shall be entitled to one vote at all meetings of the Council and to hold office or to serve on the Board of Directors if so elected.

Section 7. Honorary membership may be granted by majority vote of the Board of Directors. Honorary members will not be entitled to vote nor to be eligible to hold office. 
APPENDIX B

A Meeting of the City-County Coordinating Committee was held October 6, 1967, at 2:30 p.m., at the llultnomah County Court House.

Present Were: llayor Schrunk, presiding; City Commissioners Bowes, Earl, Grayson, and Ivancie; County Commissioners Aylsworth, Eccles, Gleason, Gordon, and Mosee.

ITEM 1. COUNCIL ON AGING

MAYOR SCHRUNK:

At our March 13, 1967 meeting, this body appointed an Ad Hoc Interim Committee to study the problems of the Council for the Aging, and to bring the report back to the joint meeting. It is my understanding there has been some material provided each of the Commissioners for this meeting, and that Mr. Goldsmith is now prepared to make a report to the joint Council.

GERSON F. GOLDSMITH, ATTORNEY, 901 EXECUTIVE BLDG.:

Mr. Chairman, Members of the Coordinating Committee:

I am speaking as the Chairman of the City-County Council on

Aging. As sort of a backdrop for my report, I would like to remind you of a few facts, of which you were probably aware when you passed your Resolution providing for the Interim Committee.

There are approximately 70,000 people in Multnomah County over the age of 65 , a sizable percentage of our population, and a population percentage that is bound to be increasing. Many of these people, because they have problems different than those of us in the younger 
brackets, have difficulty in solving the sort of problems to which they are subject. Many of them are lonely--they live alone; they are no longer engaged in raising families, or employed. Many are confused. A good many of them feel out of the ria in stream of the community life. However, many of these people have talents the comiunity could well use. illany of these people are badly housed; many of them are poorly nourished.

It is true that there are a great number of services available in this community for people over 65. Perhaps one of the problems is that there are such a number and variety of services, such a variety that even a well-educated, self-supporting elder person would have some difficulty in selecting the appropriate service for the problem with which he is confronted; and, of course, the large number of people who are not well-educated, who do not have sufficient means, would have an even greater problem in finding these services and utilizing them.

The Federal Government, in 1965, in passing the 01 der Americans Act, recognized the serious problem confronting the older people in this country. The State of Oregon has a similar recognition of the problem, in recognizing and commencing the existence of a State Program on Aging. I am sure this was what was in your mind when in March of this year, you passed the resolution providing for this Council on Aging. At that time, you appointed nine lay members to this Council, and you directed that representatives of the City and County, presumably members of their Health Bureaus, would be ex-officio 
members. At that time, you adopted a very well-phrased resolution, called, "A Proposal for Council on Aging," that has been the guideline of this Council on Aging. We have assumed that when this proposal was adopted, you meant what you said, and that this proposal should be the direction that we should follow in our deliberations. Since that time--and we commenced our meetings about March 29-we have been meeting about every ten days, in an effort to carry out the charge laid down to us in this proposal.

One of the proposals was that we adopt by-laws. We adopted by-laws, with the assistance of the Deputy District Attorney. You have a copy of our by-laws in the green pamphlet that has been furnished you, some month ago, and you will see the index tab on it. The by-laws are not entirely consistent, I might add, with the contract which has been prepared for adoption by the City-County Coordinating Committee. Those inconsistencies can be worked out. I don't think I will take time to comment on these right now... ... Commissioner Gordon questioned whether it would be appropriate for both bodies to review this, as to whether we want to do this and take action next time, or whether the Board wants to take action at this time.

By unanimous consent, the motion was withdrawn.

Commissioner Gordon made a motion, which was seconded, that this subject matter be continued until the next regular meeting of the Coordinating Committee.

The motion being put resulted in Yeas, Comissioners Mosee, 
Ivancie, Grayson, Gordon, and Mayor Schrunk, 5; Nays, Commissioners Earl, Gleason, Bowes, and Aylsworth, 4 ; whereupon the motion was declared carried.

ITEM 4. ESTABLISHMENT OF REGULAR MEETING DATE

Mayor Schrunk brought up the difficulties of the present situation, leaving the meeting date up to a joint agreement between himself and the Chairman of the Board, suggesting a regular date, with the Board Chairman and the Mayor authorized to call special meetings between, if necessary.

Commissioner Grayson made a motion, which was seconded by Commissioner Aylsworth, that a regular meeting date be set for 2:00 $\mathrm{pm}$, every two months, on the second Monday.

There was discussion, and it was agreed that this room would be used, and special meetings could be at the City Hall.

The motion being put resulted in unanimous Yeas; whereupon the motion was declared carried.

At $5: 20 \mathrm{pm}$, the meeting adjourned. 


\title{
APPENDIX C
}

\author{
BY-LAWS \\ of \\ THE CITY-COUNTY COUNCIL ON AGING \\ PORTLAND AND MULTNOMAH COUNTY
}

\section{ARTICLE I - THE COUNCIL}

SECTION 1 - NAME

The name of the organization shall be the City-County Council on Aging of Portland and Multnomah County.

\section{SECTION 2 - SIZE}

The Council shall consist of not less than nine and not more than twelve regular members. The City Council and the Board of County Conmissioners shall each appoint an ex-officio member.

\section{ARTICLE II - OBJECTIVES}

The goals and objectives of the Council shall be as follows:

1. To develop broad policy goals in dealing with the problems of the aged and aging in Portland and Multnomah County.

2. To plan, organize and supervise the administration of programs of service for the aged and aging.

3. To coordinate programs of services for the aging in order to minimize duplication. 
4. To prepare, publish, and disseminate educational material dealing with the health and welfare of the older people.

5. To work with the state and federal governments in securing grants to finance programs of service to the aging.

6. To report and make recommendations to the City Council and the Board of County Commissioners periodically on the status and needs of older people in the community. 
APPENDIX D

\section{SPECIAL SERVICE DEFINITIONS}

Jointly established by local Area Agency on Aging staff, Oregon State Program on Aging and Administration on Aging in 1974.

1. CASE PLANNING/CASE MANAGEivent: Problem solving through extended referral in which professionals or para-professionals apply their knowledge to problems presented by clients with the goal of assisting:clients to do one or both of the following: (1) recognize and institute personal changes that will lead to a more satisfactory life; (2) understand and utilize appropriate community services which will assist him in leading a more satisfactory life.

2. COMMUNITY EDUCATION: Providing instruction on a group or individual basis on subjects of interest or need including consumer and nutrition education, which are designed to provide individuals with opportunities to acquire knowledge and skills suited to their needs, interests and capabilities through either formal academic courses or informal methods, with a view toward either vocational or personal enrichment.

3. CONGREGATE DINING: Providing meals which contain at least one third of the daily recommended dietary allowances to individuals in a group setting. 
4. DETOXIFICATION: Treatment provided at a facility to a person for complete withdrawal from alcohol or drugs.

5. EMERGENCY ASSISTANCE: The direct provision of fuel, food, clothing, or assistance with utility and/or rent payments on an emergency basis when funds or resources are unavailable from other resources.

6. EMPLOYMENT COUNSELING: Employment information and advice by a knowledgeable person which results in increased knowledge and awareness of employment opportunities, including job readiness, skills assessment, etc.

7. EMPLOYMENT SERVICES: Providing employment information, counseling, and referral which may result in placement on a job.

8. ESCORT: Providing personal assistance to an individual outside the home who is confused, infirm or a likely victim of crime in order to ensure a completed journey, to accomplish a task, or to receive service(s).

9. FINANCIAL ASSISTANCE: The provision of income maintenance including Welfare and Social Security benefits, food stamp assistance, and subsidized rent payments.

10. FRIENDLY VISITATION: A supportive program in which a home visit is made to an individual to relieve loneliness. The friendly visitor may provide conversation, encouragement and basic companionship and may perform certain tasks such as writing letters, shopping, mending, etc. The friendly visitation programs aim to encourage the broadened socialization of isolated individuals. 
11. GUARDIANSHIP: A plan for care, based on legal action, implemented to protect the individual from neglect or exploitation through assigning the power of attorney to a responsible individual.

12. HOME HEALTH CARE: Provision of medication, supervision, practical nursing care, or skilled nursing care in an individual's own home.

13. HOMEMAKER: This service involves professionally trained and supervised staff providing routine health maintenance and household activities, meal preparation, personal care, etc., with the goalof maintaining elderly persons in their own homes when a health or social problem occurs, or to help individuals return to their homes after specialized care. The goal of homemaker services is the prevention of premature institutionalization.

14. HOUSEKEEPER: Although health services may not be indicated, in those cases where the condition of the client requires housekeeper support for maintenance in the home, chore services will be provided. Housekeeper services include simple household and other light work, household tasks and simple shopping.

15. HOUSING ASSISTANCE: Assisting an individuar in obtaining an adequate residence or living arrangement (not including financial assistance), on either a temporary shelter care or permanent basis to improve their present living arrangements or to relocate to more suitable housing when needed. 
16. HOUSING REPAIR: Simple household repairs, maintenance, or yardwork utilizing to the extent possible, donated labor and materials to enable an individual to remain in his own home when, because of frailty, financial need or other conditions, his independent living is in jeopardy.

17. INFORIATION: Providing current information on an individual basis with respect to opportunities and services available to older persons.

18. LEGAL COUNSELING: Legal information provided by a knowledgeable person, including advocacy where appropriate.

19. LEGAL SERVICES: Legal advice and counsel provided by a lawyer, including advocacy where appropriate, which resolves a senior's legal and/or consumer problem(s).

20. MEALS ON WHEELS: Hone delivery of a meal which contains at least one third of the daily recommended dietary allowance to a shut-in individuar.

21. MEUICAL EQUIPMENT: Assisting an individual in obtaining medical equipment, including hearing aids, glasses, wheel chairs, canes, walkers, dentures, etc.

22. MENTÁL HEALTH CARE: Psychological counseling or crisis intervention to assist an individual to overcome a period of personal stress that prevents him from functioning normally (grief, suicide, etc.).

23. NURSING HOME CARE: Providing long term maintenance or skilled nursing care to an individual in an institutional setting. 
24. OUTREACH: Field activities designed to locate and identify hard-to-reach individuals on a one-to-one basis and assist them in yaining access to needed services.

25. PREVENTIVE MEdICAL CARE: Provision of preventive medical services, including medical counseling, and screening by a trained staff person, of an individual's general physical and mental health condition; may include one or more of: eye tests, blood pressure tests, chronic disease screening, immunizations, ear care, dental care, foot care, nose and throat care or preventive treatment.

26. PROTECTIVE SERVICE: A plan for care to assist those elderly persons based on professional assessment of mental and/or physical impairment to carry out the activities of daily living implemented to protect the individual from neglect, exploitation, or hazardous situations.

27. PUBLIC GUARDIANSHIP: Guardianship provided through the Public Guardian.

28. RECREATION: Leisure time activities provided in a group setting.

29. REFERRAL: Services which assist individuals to identify the type of assistance needed, place individuals in contact with appropriate services, and followup to determine whether services were received and met the need identified, and which provides for the maintenance of proper records for use in identifying services offered and gaps in existing service systems. 
30. SPECIAL TRAIISPORTATION: Providing on-request, portal-to-portal transportation to and from community and facility resources for the purpose of applying for and receiving services, reducing isolation, or otherwise promoting independent living, with emphasis on individuals who are, for physical, financial or safety reasons, unable to use public transportation, and who do not have access to private transportation (does not include direct subsidy for an overall transit plan or general reduced fare program for public or private transit system).

31. SUBSIDIZED EMPLOYMENT: Placement of an elderly individual in a publically financed position of eriployment.

32. TELEPHONE REASSURANCE: Providing telephone calls at a specific time and on a regular basis, to individuals who live alone or are temporarily alone to determine if they are safe and well, if they require special assistance, and to provide psychological reassurance.

33. THERAPY: Physical or occupational therapy designed to assist an individual to overcome a handicapping condition.

34. VOLUNTEER OPPORTUNITIES: Providing an opportunity for seniors to volunteer their time and skills in a useful manner.

35. BANKING/CREDIT: Providing an opportunity for seniors to banking and credit services to assist them in shopping without having to carry cash with them.

36. CLIENT REPRESENTATIVE: An activity whereby a person acts as the representative of a client to perform such tasks as purchasing 
food, personal items, drugs, banking, and paying personal bills using the clients' personal funds based on the clients case plan determined through the service of case planning. 
APPENDIX E

$$
\begin{gathered}
\text { BY-LAWS } \\
\text { of }
\end{gathered}
$$

THE ADVISORY BOARD OF THE SENIOR ADULT SERVICE CENTER

\section{ARTICLE I--NAYE}

Section 1. - Name

The name of the committee shall be the Advisory Board of the Senior Adult Service Center.

Section 2. - Size

The Advisory Committee shall consist of nine (9) members.

\section{ARTICLE II--PURPOSE}

Section 1.

To work with the Director of the Senior Adult Service Center and in that capacity provide policy, advise, and evaluate and monitor the programs of service provided by the Center.

\section{Section 2.}

To coordinate programs of service for Senior Adults in the Portland Model City Neighborhood.

Section 3.

To periodically report and make recommendations to the CityCounty Council on Aging, Portland's Model City Program, and to Senior Citizens of lodel Cities as to the status of the Senior 
Adult Service Center and the needs of older persons in the Portland Model Neighborhood.

\section{ARTICLE III--MEMBERS}

Section 1. - Membership

A11 members of the Advisory Board must be at least 55 years of age and live in the Portiand Model City Neighborhood.

Term of Office

Each member shall hold a position designated by a number from 1 through 9. Each member shal1 serve for a term of three years except that the first members appointed to fill positions 1, 5, and 9 shall expire one year from the date of their appointment and the terms of members appointed to fill positions 2, 4, and 6 shall expire two years from the date of their appointment. Thereafter, members appointed shall serve a full term. Section 2. - Voting

A11 voting rights shall be vested in each member who shall be entitled to one vote with respect to any question or matter at a meeting. 


\title{
APPENDIX $F$
}

\author{
BY-LAWS \\ of
}

THE TASK FORCE OF PROJECT ABLE

(A BETTER LIFE FOR THE ELDERLY)

\section{ARTICLE I NAIIE}

The name of the planning body of the Multnomah County Areawide Program on Aging shall be the Task Force of Project ABLE (A Better Life for the Elderly).

\section{ARTICLE II PURPOSE}

The Task Force shall be responsible for guiding the development and implementation of Project ABLE, which is designed to demonstrate alternatives to institutional care for the elderly. Specific responsibilities shall include:

a. Comprehensive planning with emphasis upon:

1. Coordination of existing programs.

2. Alternative and/or innovative solutions to existing problems.

3. Maintenance and use of updated data.

4. Involvement of the elderly in all decision-making.

5. Invitation of individuals with needed knowledge to testify on major issues before action is taken. 
b. Implementation of the demonstration project components within the comprehensive plan.

c. Continued planning and evaluation.

\section{ARTICLE III STRUCTURE}

Section 1. Membership

Hembership on the Task Force shall be open to representatives of senior organizations and individuals interested in the purpose and goals of Project $A B L E$ and of representatives from public and private agencies having programs affecting the elderly. The City-County Council on Aging shall invite these organizations to designate one representative from each to serve on the Task Force.

This membership sha11 include at least 21 persons representing geographical areas, senior citizens groups, agencies serving older adults and minorities.

Section 2. Membership Selection

The City-County Council on Aging shall invite individuals, shall invite organizations and agencies to designate representatives, and shall be responsible for ensuring that the minimum representation requirements are met. The right of membership shall be withdrawn from an organization or agency that fails to send an official representative or an alternative to three consecutive meetings. 